\title{
Multilevel Regulation of Peroxisomal Proteome by Post-Translational Modifications
}

\author{
Luisa M. Sandalio ${ }^{1, *}$, Cecilia Gotor ${ }^{2}\left(\mathbb{C}\right.$, Luis C. Romero ${ }^{2} \mathbb{(}$ and Maria C. Romero-Puertas ${ }^{1}$ \\ 1 Department of Biochemistry and Cellular and Molecular Biology of Plants, \\ Estación Experimental del Zaidín, CSIC, 18008 Granada, Spain; maria.romero@eez.csic.es \\ 2 Institute of Plant Biochemistry and Photosynthesis, CSIC and the University of Seville, 41092 Seville, Spain; \\ gotor@ibvf.csic.es (C.G.); lromero@ibvf.csic.es (L.C.R.) \\ * Correspondence: luisamaria.sandalio@eez.csic.es; Tel.: +34-958-181-600
}

Received: 25 August 2019; Accepted: 26 September 2019; Published: 1 October 2019

check for updates

\begin{abstract}
Peroxisomes, which are ubiquitous organelles in all eukaryotes, are highly dynamic organelles that are essential for development and stress responses. Plant peroxisomes are involved in major metabolic pathways, such as fatty acid $\beta$-oxidation, photorespiration, ureide and polyamine metabolism, in the biosynthesis of jasmonic, indolacetic, and salicylic acid hormones, as well as in signaling molecules such as reactive oxygen and nitrogen species (ROS/RNS). Peroxisomes are involved in the perception of environmental changes, which is a complex process involving the regulation of gene expression and protein functionality by protein post-translational modifications (PTMs). Although there has been a growing interest in individual PTMs in peroxisomes over the last ten years, their role and cross-talk in the whole peroxisomal proteome remain unclear. This review provides up-to-date information on the function and crosstalk of the main peroxisomal PTMs. Analysis of whole peroxisomal proteomes shows that a very large number of peroxisomal proteins are targeted by multiple PTMs, which affect redox balance, photorespiration, the glyoxylate cycle, and lipid metabolism. This multilevel PTM regulation could boost the plasticity of peroxisomes and their capacity to regulate metabolism in response to environmental changes.
\end{abstract}

Keywords: nitric oxide; S-nitrosylation; nitration; peroxisome; persulfidation; phosphorylation; posttranslational modifications; reactive oxygen species; sulfenylation

\section{Introduction to Peroxisomal Metabolism, Function, and Dynamics}

Peroxisomes, which are ubiquitous in all eukaryotes and essential for the development and stress responses of yeast, plants and animals, are organelles surrounded by a single membrane, with a very simple ultrastructure. They are involved in metabolic pathways, such as fatty acid $\beta$-oxidation, branched amino acid catabolism, ureide metabolism, reactive oxygen species (ROS), and reactive nitrogen species (RNS), some of which are shared cross-kingdoms [1,2]. However, other important specific metabolic functions such as photorespiration are exclusively associated with plant peroxisomes (Figure 1). A common characteristic of peroxisomes from different organisms is high ROS production which, in plants, is associated with metabolic pathways, such as fatty acid $\beta$-oxidation, ureide metabolism, sulfite oxidation, polyamine catabolism, and photorespiration. These organelles also have a great capacity to remove ROS thanks to a complex antioxidative defense systems such as catalase (CAT), superoxide dismutase (SOD), glutathione-S-transferase, and the ascorbate-glutathione cycle $[1,3]$. In addition, peroxisomes are an important source of RNS, thus it was reported to contain NO and GSNO, the latter acting as a cellular reservoir of NO [1,4].

Peroxisomal proteins are encoded in the nucleus and imported into the peroxisome throughout peroxisomal proteins called peroxines (PEXs). Peroxines PEX3, PEX6, and PEX19 participate in 
inserting peroxisomal membrane proteins (PMPs) into peroxisomal membrane (group II PMPs) or into a peroxisome-destined region of the ER membrane (group I PMPs) [2]. Peroxisomal matrix proteins are imported through soluble receptor PEX5, which recognizes proteins containing peroxisomal targeting signal 1 (PTS1) associated with the $C$ terminal, and through soluble receptor PEX7 which recognizes peroxisomal targeting signal 2 (PTS2) associated with the $\mathrm{N}$ terminus, using a docking site composed of PEX13 and PEX14 [3]. Some matrix proteins do not contain PTSs and are imported into the peroxisome by piggyback [5]. The number of peroxisomes can be increased by fission during cell division or by proliferation, a process associated with stress conditions $[6,7]$ which takes place through peroxisome elongation, constriction, and fission and is controlled by PEX11. This process is controlled by PEX11, which consists of five isoforms from PEX11a to PEX11e, dynamin-related proteins (DRPs), and fission proteins FISSION1 (FIS1) [6]. DRP3A and DRP3B regulate the division of peroxisomes and mitochondria, while DRP5 acts independently of DRP3 and is involved in the division of peroxisomes, chloroplasts, and mitochondria [8]. FIS1 has two homologs, FIS1A and FIS1B, which are shared by both peroxisomes and mitochondria [6].

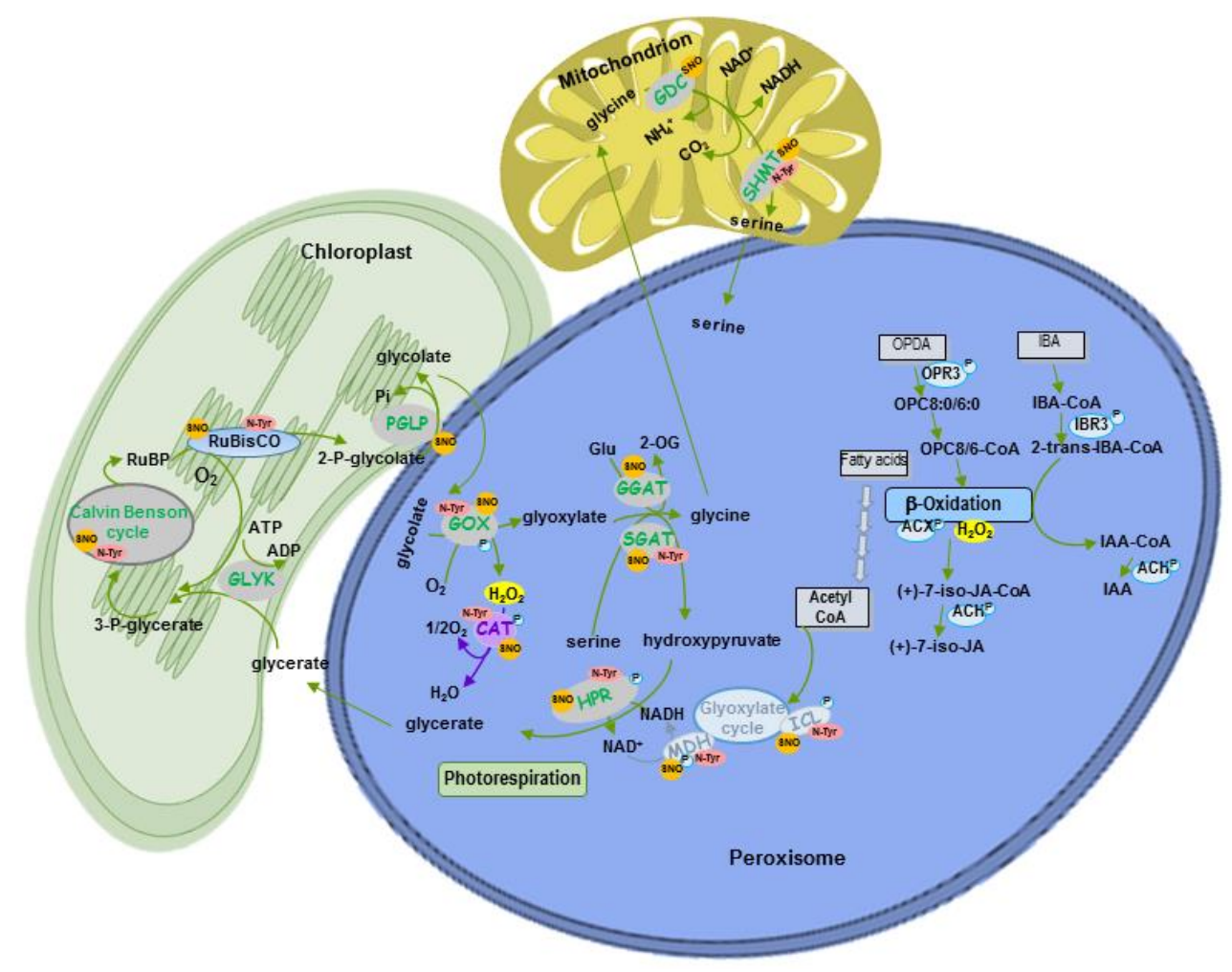

Figure 1. Representative scheme of the main peroxisomal metabolic pathways and their regulation by NO-dependent protein post-translational modifications (PTMs) and phosphorylation. Ph, phosphorylation; SNO, S-nitrosylation; N-Tyr, nitration.

Peroxisomes are highly dynamic organelles that are able to change their metabolic pathways, number, size, morphology, relationship with other organelles, and even speed of movement depending on development stage, cell type, tissue, and stress conditions $[1,3,7]$. Peroxisomes have a close relationship with other organelles. Oil bodies and peroxisomes collaborate in seeds and cotyledons to provide energy during the first stage of seedling germination and growth by channeling triacylglycerides from the oil bodies to peroxisomal $\beta$-oxidation, with Acyl CoA oxidase being one of the first enzymes involved in this process, which also produces $\mathrm{H}_{2} \mathrm{O}_{2}$ (Figure 1) $[2,9,10]$. Acetyl-CoA from fatty acid $\beta$-oxidation is then converted into $\mathrm{C} 4$ acids via the glyoxylate cycle, which is present in a type of peroxisome called glyoxysome (Figure 1). The $\mathrm{C} 4$ compounds are then transported to the mitochondria, where they can be either converted to malate and transported to the cytosol for gluconeogenesis, or can 
be used as substrates for respiration (Figure 1) [2,11]. The glyoxylate cycle is composed of the following enzymes: Isocitrate lyase (ICL) and malate synthase (MS), which are unique to this cycle, as well as malate dehydrogenase (MDH), citrate synthase (CS), and aconitase (AC) which are common to the glyoxylate cycle [11] (Figure 1) and the tricarboxylic acid (TCA) cycle in mitochondria [2]. Fatty acid $\beta$-oxidation is involved in several important processes including synthesis of indolacetic acid (IAA) from indolebutyric acid (IBA), jasmonic acid from 12-oxophytodienoic acid (OPDA) generated in the chloroplast (see [10] for review), ubiquinone, as well as secondary metabolites like benzoic acid (BA) and phenylpropanoids (Figure 1) [2,12,13].

Photomorphogenesis and senescence are examples of the metabolic plasticity of peroxisomes. During photomorphogenesis, light triggers a shift in the metabolism from fatty acid $\beta$-oxidation and the glyoxylate cycle to photorespiration or the oxidative photosynthetic carbon cycle, in which sugars are oxidized to $\mathrm{CO}_{2}$ under light in a complex pathway where several enzymes are distributed among chloroplasts, peroxisomes, and mitochondria requiring close physical contact between all these organelles [2] (Figure 1). One of the key peroxisomal enzymes in photorespiration is glycolate oxidase which oxidizes glycolate (produced in chloroplasts), giving rise to glyoxylate and $\mathrm{H}_{2} \mathrm{O}_{2}$. Glyoxylate is further transaminated to glycine by glutamate:glyoxylate aminotransferase, while glycine is transported to mitochondria to be converted to serine, producing $\mathrm{CO}_{2}$, ammonia and NADH (Figure 1). Serine is transported to peroxisomes where it is used to generate hydroxypiruvate by serine:glyoxylate aminotransferase. Hydroxypiruvate is, in turn, reduced to glycerate by hydroxypiruvate dehydrogenase and is transferred to the chloroplast where it is converted to 3-phosphoglycerate (Figure 1) [14]. The metabolic transition during photomorphogenesis requires the degradation of specific proteins, which become obsolete or of whole organelles, and imports of new proteins into peroxisomes to maintain photorespiration [2]. Peroxisomal protease LON2 plays an important role in the selective degradation of glyoxylate-dependent matrix proteins during this metabolic transition, although selective degradation of peroxisomes by pexophagy also helps to regulate the thiolase associated to fatty acid $\beta$-oxidation $[15,16]$. Both LON2 and pexophagy regulate peroxisome abundance [7,15], with LON2 chaperone activity acting as a pexophagy inhibitor [15]. During senescence, an opposite transition takes place through the down-regulation of photorespiration, while glyoxylate-associated proteins are enhanced [17].

Organelle communication is also an important issue with regard to signaling and metabolic network regulation. Peroxisomes are highly dynamic organelles whose speed of movement can change in response to disturbances in their environment which are regulated by $\mathrm{ROS}$ and $\mathrm{Ca}^{++}[7,18]$. Peroxisomal extensions, also called peroxules, can be observed under oxidative stress conditions; although their precise function is unclear, it has been suggested that they are involved in peroxisome elongation prior to division [19] and also in the mechanism that regulates rapid cell responses to redox changes and signaling [7]. PEX11a has been reported to be involved in peroxule formation triggered by ROS-dependent NADPH oxidases [7]. However, the redox-sensitive proteins involved in peroxisomal protein import and proliferation in plants have yet to be identified, which would help us to understand the signaling network that governs rapid responses to environmental changes and the role of ROS/RNS in this process. In yeast and human fibroblasts, PEX5 has been reported to act as a redox switch that regulates the import of peroxisomal matrix proteins into peroxisomes [20,21], although it has not, so far, been described in plants. In addition, peroxisome population control can be regulated by pexophagy at the basal level [22] and under stress conditions [23,24], which could be crucial for rapid cell responses.

Peroxisomes, which share metabolites with other organelles and are involved in the biosynthesis of different hormones (jasmonic acid, indolacetic acid and salicylic acid) and signals (ROS, RNS) and in the perception of rapid responses to stress, play an important role in metabolism and transcriptome regulation [1]. The perception of environmental changes, as well as acclimation and adaptive responses to these changes in plants, are complex processes which involve different signal transduction pathways acting in a coordinated way to finally regulate gene expression and protein functionality through post-translational modifications, giving rise to elaborate, specific rapid responses. Although gene 
transcription modulation governs protein content, gene expression does not always coincide with protein activity [4]. This is due to protein post-translational modifications (PTMs) that can regulate protein activity, localization, inter-protein interactions and degradation, giving rise to rapid finely tuned regulation of protein function and consequently of metabolic pathways and signaling processes [25]. Over 200 different PTMs have been reported in mammals and plant cells [26], including carbonylation, $S$-nitrosylation, nitration, phosphorylation, ubiquitination, persulfidation, glutathionylation and SUMOylation, whose functionality can differ depending on the protein. PTM regulation of proteins becomes increasingly complex due to the synergistic or antagonistic interplay between the different PTMs. In this review, we provide up-to-date information on putative PTMs of peroxisomal proteins, as well as a framework to further investigate the function and crosstalk of PTMs in peroxisomes, with a particular focus on those associated with ROS and NO.

\section{Post-Translational Modification of Peroxisomal Proteins}

To analyze putative PTMs capable of modulating peroxisomal proteins, we compared a list of peroxisomal candidate proteins from Arabidopsis thaliana, which undergo PTMs, from the following databases: Plant PTM Viewer [27]; TAIR [28] with the aid of GO codes for peroxisomes and glyoxysomes (GO: 0005777 and GO: 0009514, respectively); and NCBI [29] with a list of peroxisomal proteins [30] using the Venny tool [31]. Putative peroxisomal proteins from these databases were selected from proteomic studies available in the literature [30] and taking into account putative PTSs sequences [28]. Approximately $35 \%$ of the putative peroxisomal proteins were identified as PTM targets. To provide an overview of the putative role of peroxisomal protein PTMs, the proteins were classified into the principal peroxisomal and cellular pathways. However, further research is required to demonstrate that most of these proteins are modified by the PTMs described in this review and to determine their function in regulating metabolism and signaling events.

\section{1. $\mathrm{H}_{2} \mathrm{O}_{2}$-Dependent Post-Translational Modifications}

\subsubsection{Protein Sulfenylation}

Oxidative protein modifications, such as sulfenylation, sulfinylation and sulfonylation, as well as intra- and inter-molecular disulfide bond formation, are rapid and reversible mechanisms (except irreversible sulfonylation) to regulate protein function in living cells in response to changing redox states [32]. Sulfur-containing amino acids such as cysteine are highly susceptible to oxidation by $\mathrm{ROS}$ such as $\mathrm{H}_{2} \mathrm{O}_{2}$. This reactive oxygen species leads to reversible oxidation of cysteines to $\mathrm{SOH}$ which is highly reactive and can be overoxidized to sulfinic acid $\left(\mathrm{SO}_{2} \mathrm{H}\right)$ and sulfonic acid $\left(\mathrm{SO}_{3} \mathrm{H}\right)$ [33] under excessive $\mathrm{ROS}$ accumulation conditions. Electrophilic $\mathrm{SOH}$ also reacts with a free thiol on the same protein or other proteins, giving rise to the formation of intramolecular and intermolecular disulfides, and can even react with GSH-promoting S-glutathionylated disulphides [33]. $\mathrm{SOH}$ also forms sulfenylamide through the reaction of sulfur with the backbone nitrogen of the adjacent residue. Due to their transient nature, these sulfur modifications, which can be reversibly reduced by thioredoxin and glutaredoxin pathways, are regarded as redox switches (for review see [33]). For example, OxyR, the $\mathrm{H}_{2} \mathrm{O}_{2}$-sensitive transcription factor in E. coli, becomes active when oxidized by $\mathrm{H}_{2} \mathrm{O}_{2}$ and inactive when reduced [33]. An example from peroxisomal proteome is 3-ketoacyl-CoA thyolase [34]. As reported with regard to Arabidopsis cytosolic malate dehydrogenase 1, sulfenylated cysteines can mediate disulfide formation to prevent protein overoxidation and are also involved in the protein catalytic site and therefore in regulating the function of this protein as well as in the case of peroxisomal dehydroascorbate reductase 2 (DHAR2) [35]. Thus, the effect of this PTM on proteins differs depending on the protein involved, giving rise to reversible or irreversible inactivation by overoxidation [33]. However, the role of sulfenylation in protein degradation due to protein overoxidation is not fully understood [36]. 
Cysteine sulfenylation has been reported to be crucial for redox signaling, with several sulfenylated proteins suggested to be oxidative stress sensors [37]. The identification of cellular sulfenylated proteins and sulfenome could therefore be very useful in detecting potential redox sensors of ROS signaling pathways. Mass spectrometry-based techniques and proteomics have been used to identify sulfenylated proteins in plants (for review see [33]). A biotin switch method originally designed to detect protein $S$-nitrosylation has been adapted by changing the reducing agent from ascorbate to arsenite in order to identify sulfenylated proteins (for review see [32]). Western blot analysis using an anti-cysteine sulfenic acid antibody also enables sulfenylated proteins to be identified [36]. To image in vivo sulfenylated proteins, 5,5-Dimethyl-1,3-cyclohexanedione (dimedone), containing a nucleophilic carbon that selectively reacts with electrophilic sulfenic acids, as well as other more permeable analogs (DAz-1, DAz-2 and DYn-2), have been used (reviewed by [33]). A genetically-encoded probe based on YAP1 from yeast has been successfully used to analyze sulfenomes in Arabidopsis cell cultures [32,35].

Sulfenylated Peroxisomal Proteins

Using different proteomic analytical techniques, the following Arabidopsis peroxisomal proteins have been identified: Monodehydroascorbate reductase 1 and 4, found to be targets of Trx in Arabidopsis roots [36], and glutathione-disulfide reductase (GR). Both GR and MDHAR are important components of the ascorbate-glutathione cycle involved in antioxidant defenses. The glyoxalase 1 (GLX1) homolog is another putative sulfenylated protein involved in methylglyoxal detoxification and protection against carbonyls [38]. Other sulfenylated proteins are Acyl-CoA oxidase 1 (ACX1) and peroxisomal 3 -ketoacyl-CoA thiolase 3 (AtKAT3), both involved in fatty acid $\beta$-oxidation. AtKAT2 is inactive in the oxidized dimer form and active in the reduced monomer form; depending on the peroxisomal redox environment, AtKAT 2 controls $\beta$-oxidation and metabolite channeling by regulating the formation of a complex containing thiolase and multifunctional protein 2 (MFP2) [34]. The protein phosphatase 2A $55 \mathrm{kDa}$ regulatory subunit $\mathrm{B}$ alpha isoform from Medicago has also been identified as a target of sulfenylation [36]. However, the effect of sulfenylation on proteins such as ACX and GLX has not been fully explained.

\subsubsection{Protein Carbonylation}

Oxidative damage to proteins can be caused by excessive ROS-induced oxidation, giving rise to a variety of covalent protein modifications such as carbonylation of specific amino acids. The most frequently studied oxidation-dependent PTM is protein carbonylation which mainly targets proline, lysine, arginine, and threonine [39]. Carbonylation is caused by nucleophilic attacks on the CO group by $\mathrm{OH}$ radicals produced in Fenton-type reactions involving $\mathrm{H}_{2} \mathrm{O}_{2}, \mathrm{O}_{2}{ }^{-}$and metals (mainly $\mathrm{Fe}$ and $\mathrm{Cu}[40]$ ). Oxidation of proline or arginine side chains forms glutamic semialdehyde, while lysine oxidation results in aminoadipic semialdehyde, thus introducing carbonyl groups $(R-C=O)$ into the protein structure [41]. The hydroxyl group of threonine side chains can also be oxidized to form the carbonyl group [41]. Protein carbonylation is regarded as an oxidative stress marker which gives rise to the inactivation and further degradation of proteins [42,43]. Although carbonylation is an irreversible protein modification, protein decarbonylation has been reported in mammals [41]. Several carbonylated proteins, previously characterized in mammals, yeast, and bacteria, have also been found to be oxidized in plants. This suggests that protein carbonylation could be more than a random process and be involved in controlling common biological functions in living organisms [44]. Protein carbonylation has been reported at different stages of the plant cycle [44]. Proteins damaged by carbonylation are preferentially degraded by proteasome 20S [45] but can also be removed by autophagy [46].

Protein carbonylation can be analyzed using a method based on derivatization with 2,4-dinitrophenylhydrazine (DNPH) which reacts with the carbonyl group of aldehyde or ketone and forms a hydrazone derivative (DNP), detectable by Western blot with the aid of specific antibodies against DNP $[42,47]$ and by HPLC $[48,49]$. 
Carbonylated Peroxisomal Proteins

As mentioned above, peroxisomes, which are a major cellular source of ROS, are vulnerable to oxidation mainly under stress conditions when ROS break through antioxidant defenses. Under control conditions, peroxisomal proteins show a basal level of carbonylation which is increased by stress induced by Cd treatment [42], Cu plus ascorbate [50] and salinity [48]. Although the Plant PTM Viewer does not identify any putative peroxisomal targets of carbonylation, by using DNPH derivatization and HPLC several carbonyl target proteins have been identified in Arabidopsis plants, mainly associated with nucleic acid metabolism (nucleoside diphosphate kinase, NDPK), antioxidant defenses (CAT), and fatty acid $\beta$-oxidation (AIM1) [48]. The carbonylated proteins detected in response to $\mathrm{Cd}$ in pea plants include CAT, GR, and Mn-SOD, while MS, IL and MDH have been reported in castor bean endosperm exposed to $\mathrm{Cu}$ and ascorbate [50]. The activity of the target protein is considerably reduced by this type of protein modification [42,50], while carbonylated proteins have been found to be efficiently recognized and degraded by peroxisome proteases [42]. It has been suggested that inactive oxidized CAT is involved in recognizing oxidized peroxisomes to be targeted for pexophagy under basal and stress conditions, as phagophores and autophagy markers are located close to the peroxisomal core containing inactive catalase [22,23,51]. However, the mechanism involved remains unknown, as the peroxisomal matrix enzyme CAT is unable to interact directly with ATG8 or the receptor NBR1.

\subsection{NO-Dependent PTMs}

Nitric oxide (NO), a highly reactive gaseous free radical, plays an important regulatory role. Over the last twenty years, NO has been involved in plant processes ranging from development [52,53] and defence responses to both biotic and abiotic stresses [54-56]. Up to now, NO's principal mode of action in plants has been reported to be non-classical signalling, which depends on covalent protein post-translational modifications. These PTMs are carried out by a sequence of reactive nitrogen species (RNS) resulting from the reaction of NO with other signalling molecules such as free radicals. The best known NO-dependent PTM in plants is S-nitrosylation, also called S-nitrosation (for review see [57] and [58]) which involves the formation of a nitrosothiol in a Cys residue and modifies the function, location, and stability of a number of proteins $[59,60]$. S-nitrosylation facilitates gene regulation through the modification of transcription factors (TFs) [61,62] and the DNA methylation index by altering enzymes involved in the methylation cycle [63]. NO interacts with most phytohormone-dependent signalling pathways through the $S$-nitrosylation of enzymes involved in biosynthetic pathways and/or phytohormone-dependent regulatory proteins [64-66] and regulates ROS levels through the $S$-nitrosylation of ROS-producing and -scavenging enzymes [67]. In plants, S-nitrosylation may result in the establishment of a disulfide bond, which is regarded as an intermediate path leading to a more stable modification [68]. In large-scale proteomic studies, over 1000 proteins have been shown to be putative targets of $S$-nitrosylation in plants $[69,70]$, although the functional impact of this PTM has only been analyzed in approximately $2 \%$ of these proteins $[60,70,71]$.

Less is known about the NO-dependent PTM tyrosine nitration, associated with nitrogen dioxide $\left(\mathrm{NO}_{2}\right)$ and peroxynitrite $\left(\mathrm{ONOO}^{-}\right)$, whose impact on protein functionality in plants has also been described [72]. Certain gaps in our knowledge of this PTM, such as its reversibility in plants, remain. $\mathrm{ONOO}^{-}$can also induce the production of oxygenated forms of Cys residue, such as sulfenic acid $(-\mathrm{SOH})$, sulfinic acid $\left(-\mathrm{SO}_{2} \mathrm{H}\right)$ and sulfonic acid $\left(-\mathrm{SO}_{3} \mathrm{H}\right)$, and $S$-glutathionylation [59]. Fewer putative targets of nitration have been identified in plants as compared to those of S-nitrosylation [73-75]. On the other hand, the best known direct modification of NO in animal systems, though less studied in plants, is the formation of complex bonds with transition metal ions in heme groups, such as guanylate cyclase, Cyt p450, and haemoglobin [76], with the haemoglobin heme group having also been described in plants [77-80]. 
Peroxisomal Targets of NO-Dependent PTMs

NO has been shown to be present in plant peroxisomes under physiological and stress conditions [81-83]. Several studies, mostly based on the use of NOS inhibitors, have suggested the presence of NOS-like activity in plants, which has also been described in peroxisomes [83], although no orthologue to the animal NOS-like gene has been found in land plants [84]. Peroxisomes also contain xanthine oxidase (XOD), which is capable of generating NO under special conditions [85]. The NO derivatives, peroxinitrite (ONOO-), and nitrosoglutathione (GSNO), have also been observed in peroxisomes $[4,86]$, whose formation is promoted by $\mathrm{NO}$ in the presence of $\mathrm{O}_{2}{ }^{-}-$ and GSH, respectively. The protein targets of NO-dependent PTMs are therefore expected to be present in these organelles. Unless specifically located or associated with a particular gene, it has been difficult to pinpoint the location of the proteins obtained in the organelles using large-scale proteomic analyses. The peroxisomal targets of NO-dependent PTMs were obtained from large-scale S-nitrosylation and nitration proteomic analysis in Arabidopsis plants and compared with the in house peroxisomal protein list [71,74,87-89] and are described in Table 1 and Table S1. Approximately $8.4 \%$ of the putative peroxisomal proteins are considered to be targets of $S$-nitrosylation (Table S1). However, only 1.6\% are regarded as putative targets of Tyr-nitration (Table S1), suggesting that more specific studies, with purified organelles, may be required to determine the actual number of nitration targets. Peroxisomal putative $S$-nitrosylated proteins are involved in antioxidant defences (DHAR, GR, and CAT), photorespiration (alanine-2-oxoglutarate aminotransferase 2, HPR, alanine: glyoxylate aminotransferase, glutamate: glyoxylate aminotransferase), the glyoxylate cycle (isocitrate dehydrogenase, NAD-malate dehydrogenase 1 and 2 , and citrate synthase 2); $\beta$-oxidation (ACX2,3 and 6, acyl-CoA synthase, 3-ketoacyl-CoA thiolase 3 and 4), the pentose phosphate cycle (6-phosphogluconate dehydrogenase family protein), the serine/threonine protein phosphatase 2A and nucleoside diphosphate kinase (Table 1 and Table S1).

A proteomic study of peroxisomes isolated from pea plants shows that six S-nitrosylation target proteins are involved in photorespiration (HPR, GOX, serine:glyoxylate aminotransferase and aminotransferase 1), $\beta$-oxidation (MDH) and the antioxidant system (CAT) [4] (Table 1). Furthermore, the $S$-nitrosylation levels of both $\mathrm{H}_{2} \mathrm{O}_{2}$-producing GOX and $\mathrm{H}_{2} \mathrm{O}_{2}$-removing CAT change under abiotic stresses such as cadmium and 2,4-D, suggesting that $S$-nitrosylation plays a role in regulating peroxisomal $\mathrm{H}_{2} \mathrm{O}_{2}$ under physiological and stress conditions by reducing the activity of these proteins [4]. Nitrated proteins, which are mainly involved in ROS metabolism (CAT, MDHAR, $\mathrm{Cu}, \mathrm{Zn}-\mathrm{SOD})$, photorespiration (MDH, GOX) and $\beta$-oxidation (MDH), have also been identified in peroxisomes [72-74,90,91] (Table 1).

\section{3. $\mathrm{H}_{2} \mathrm{~S}$-Dependent Post-Translational Modifications: Protein Persulfidation}

The perception of hydrogen sulfide $\left(\mathrm{H}_{2} \mathrm{~S}\right)$ as a toxic molecule has been superseded by an extraordinary number of studies which highlight its important role in plant physiology. $\mathrm{H}_{2} \mathrm{~S}$, which is involved in regulating various processes essential for plant performance, has been established to be a signaling molecule equal in importance to $\mathrm{NO}$ and $\mathrm{H}_{2} \mathrm{O}_{2}$ in plant systems [92,93].

$\mathrm{H}_{2} \mathrm{~S}$ plays a role in plant stress responses which enables plants to adapt to adverse conditions and positively affects seed germination, root elongation, and overall plant survival. Studies have been carried out on its involvement in drought, salinity, hypoxia, heat, as well as chilling and metal stress, while (pre) treatment with $\mathrm{H}_{2} \mathrm{~S}$ and endogenous sulfide induction have mostly been found to alleviate oxidative stress by enhancing antioxidant plant defenses [94,95].

The vital plant processes, in which hydrogen sulfide plays a signaling role, are photosynthesis [96], programmed cell death [97], and autophagy [98,99], while the number of regulated processes is continuously increasing. Another important aspect of $\mathrm{H}_{2} \mathrm{~S}$ is the regulation of stomatal movement which has major consequences for efficient plant water regulation. Various studies have shown that hydrogen sulfide plays an active role in abscisic acid-dependent signaling pathways in guard cells by 
regulating ion channel activity and interacts in a complex way with other signaling molecules and hormones [100-104].

Although much information is available on the different pathways and processes regulated by $\mathrm{H}_{2} \mathrm{~S}$, little is known about the precise mechanism of action involved. The mechanism underlying how hydrogen sulfide functions is related to its chemical properties and high level of reactivity $[95,105]$. $\mathrm{H}_{2} \mathrm{~S}$ shows a high affinity for metalloprotein metal, and sulfide inhibits the mitochondrial electron transport chain by covalently binding to the iron center of cytochrome c oxidase. Its nucleophilic properties also suggest that $\mathrm{H}_{2} \mathrm{~S}$ can act as an oxidative stress reductant by reacting with reactive oxygen species (ROS), which has been suggested as how sulfide treatment increases plant cell antioxidant capacity. Finally, sulfide is also involved in the PTM, now called persulfidation (formerly known as $S$-sulfhydration), which oxidizes cysteine thiol groups to persulfide groups (R-S-SH).

The first proteomic analyses of persulfidation in plants were carried out on Arabidopsis leaf tissues grown in soil under long-day photoperiod conditions using two different experimental methods based on specific biotin labelling of persulfide groups [106]. These analyses revealed that persulfidation is a widespread PTM in the plant proteome which is involved in a wide range of biological functions and in regulating important processes [107].

\section{Persulfidated Peroxisomal Proteins}

The proteomic analyses carried out in wild type Arabidopsis plants grown under controlled conditions identified more than 3000 proteins [107], 61 of which were assigned subcellular locations in peroxisomes (Table 1 and Table S1). These include the following enzymes identified in the antioxidant system CAT3 and $\mathrm{Cu}-\mathrm{Zn}$ superoxide dismutase 3 (SOD3); fatty acid oxidation enzymes such as ACX1, 3,4 , and 6 and two enoyl-CoA hydratase/isomerase enzymes (AIM1/ECHIA). Sulfite oxidase (SOX), which catalyzes two-electron oxidation of sulfite to sulfate derived from sulfur amino acid catabolism, was also identified.

Persulfidation can affect the subcellular localization of a protein and/or its enzymatic properties $[108,109]$. Although in vitro studies have shown that treatment with NaHS inhibits catalase activity in a dose-dependent manner, they do not specify whether this inhibition is due to cysteine persulfidation or to a sulfide reaction with the heme center [110]. Similar results have also been reported with regard to NADP-dependent isocitrate dehydrogenase and the NADP-malic enzyme from sweet pepper, in which NaHS treatment results in partial enzymatic inhibition [111,112].

The specific chemical reactions causing protein persulfidation depend on the environment [105]. This modification requires an oxidant, as hydrogen sulfide cannot directly modify cysteine residues to form a persulfide group. So, the ionic form of sulfide, the thiolate (HS-) can react with cysteine sulfenic acid (R-SOH) to form cysteine persulfide (R-SSH). Partially oxidized sulfide species such as polysulfides $\left(\mathrm{H}_{2} \mathrm{Sn}\right)$ are able to transfer sulfane sulfur $(\mathrm{S} 0)$ atoms to reduced cysteine to form persulfides or polysulfided cysteine residues (R-SSnH). The oxidative environment of peroxisomes may therefore be appropriate to form these oxidized intermediaries to enable persulfidation to take place. Despite the capacity of peroxisomes to generate different reactive oxygen and nitrogen species that can easily react with $\mathrm{H}_{2} \mathrm{~S}$, the reduced $\mathrm{H}_{2} \mathrm{~S}$ molecule has recently been detected in peroxisomes using a specific fluorescent probe [110]. 
Table 1. Peroxisomal processes and proteins regulated by multiple PTMs.

\begin{tabular}{|c|c|c|}
\hline Locus & Description & PTM_Types \\
\hline \multicolumn{3}{|c|}{ REDOX/ASC-GLU CYCLE } \\
\hline AT1G19570 & dehydroascorbate reductase & ac; na; no; nt; ro \\
\hline AT2G31570 & glutathione peroxidase 2 & ac; na; nt; ph \\
\hline AT3G24170 & glutathione-disulfide reductase & ac; mo; na; no; nt; sf \\
\hline AT3G27820 & monodehydroascorbate reductase 4 & ph; sf \\
\hline AT3G52880 & monodehydroascorbate reductase 1 & ac; mo; ph; ps \\
\hline AT4G35000 & ascorbate peroxidase 3 & ac; na; nt; ro; ub \\
\hline AT4G35970 & ascorbate peroxidase 5 & na; nt; ro \\
\hline AT1G20620 & catalase 3 & ac; na; no; nt; ph; ps; ntyr \\
\hline AT1G20630 & catalase 1 & ac; no; nt; ph \\
\hline AT4G35090 & catalase 2 & ac; na; no; nt; ph; ps; ca \\
\hline AT5G18100 & copper/zinc superoxide dismutase 3 & $\mathrm{ph}$ \\
\hline \multicolumn{3}{|c|}{ PHOTORESPIRATION } \\
\hline AT1G68010 & hydroxypyruvate reductase & ac; mo; na; no; nt; ph; ps \\
\hline AT1G70580 & alanine-2-oxoglutarate aminotransferase 2 & ac; na; no; nt; ph; ro; ps \\
\hline AT2G13360 & alanine:glyoxylate aminotransferase & ac; na; no; nt; ph; ps; ntyr \\
\hline AT3G14130 & Aldolase-type TIM barrel family protein/glycolate oxidase & ac; na \\
\hline AT3G14150 & Aldolase-type TIM barrel family protein/ glycolate oxidase & na \\
\hline AT3G14415 & Aldolase-type TIM barrel family protein/ glycolate oxidase & ac; na; ng; nt; ph; ntyr \\
\hline AT3G14420 & Aldolase-type TIM barrel family protein/ glycolate oxidase & ac; na; ng; nt; ph; ntyr \\
\hline AT4G18360 & Aldolase-type TIM barrel family protein/ glycolate oxidase 3 & ac; na; ph \\
\hline AT4G39660 & alanine:glyoxylate aminotransferase 2 & ac \\
\hline AT1G23310 & glutamate:glyoxylate aminotransferase & ac; na; no; nt; ph; ro; ub; ps \\
\hline \multicolumn{3}{|c|}{ GLUCONEO/GLYOXYLATE CYCLE } \\
\hline AT1G54340 & isocitrate dehydrogenase & na; no; ro; ps \\
\hline AT2G22780 & peroxisomal NAD-malate dehydrogenase 1 & no; nt; ps \\
\hline AT2G42790 & citrate synthase 3 & ac; $n t ; p h ; u b ; p s$ \\
\hline AT3G16910 & acyl-activating enzyme 7 & ac; nt; ps \\
\hline AT3G21720 & isocitrate lyase & na; nt \\
\hline AT3G58740 & citrate synthase 1 & ac; nt; ph \\
\hline AT3G58750 & citrate synthase 2 & ac; no; nt; ph; ps \\
\hline AT5G03860 & malate synthase & na; nt \\
\hline AT5G09660 & peroxisomal NAD-malate dehydrogenase 2 & ac; mo; no; nt; ph; ro; ps; ntyr \\
\hline
\end{tabular}


Table 1. Cont.

\begin{tabular}{|c|c|c|}
\hline Locus & Description & PTM_Types \\
\hline \multicolumn{3}{|c|}{ LIPID METABOLISM- $\beta$ OXIDATION } \\
\hline AT4G16760 & acyl-CoA oxidase 1 & ac; mo; na; nt; ps; sf \\
\hline AT5G65110 & acyl-CoA oxidase 2 & no \\
\hline AT1G06290 & acyl-CoA oxidase 3 & no; nt; ps \\
\hline AT1G06310 & acyl-CoA oxidase 6 & no; ph; ps \\
\hline AT1G20560 & acyl activating enzyme 1 & na; nt \\
\hline AT1G66120 & AMP-dependent synthetase and ligase family protein & $\mathrm{ub}$ \\
\hline AT1G77540 & Acyl-CoA N-acyltransferases (NAT) superfamily protein & na; nt; ph \\
\hline AT1G76150 & enoyl-CoA hydratase 2 & na; nt; ro; ps \\
\hline AT1G60550 & enoyl-CoA hydratase/isomerase D & ph; ps \\
\hline AT2G30200 & EMBRYO DEFECTIVE 3147 & ac; mo; nt; ph \\
\hline AT3G05970 & long-chain acyl-CoA synthetase 6 & nt; ps \\
\hline АT3G06810 & acyl-CoA dehydrogenase-like protein & ac; na; ph; ps \\
\hline АT3G06860 & multifunctional protein 2 & ac; nt; ph; ps \\
\hline AT3G51840 & acyl-CoA oxidase 4 & na; nt; ph;ps \\
\hline AT4G04320 & malonyl-CoA decarboxylase family protein & $\mathrm{ph}$ \\
\hline AT4G16210 & enoyl-CoA hydratase/isomerase A & ac; mo; na; nt; ph; ps \\
\hline AT4G27780 & acyl-CoA binding protein 2 & $\mathrm{ph}$ \\
\hline AT4G29010 & Enoyl-CoA hydratase/isomerase family & ac; mo; na; nt; ps; ca \\
\hline AT5G16370 & acyl activating enzyme 5 & na; nt \\
\hline AT5G27600 & long-chain acyl-CoA synthetase 7 & nt \\
\hline AT5G36880 & acetyl-CoA synthetase & ac; na; no; nt; ph \\
\hline AT5G42890 & sterol carrier protein 2 & mo; na; nt \\
\hline AT4G00520 & Acyl-CoA thioesterase family protein & $\mathrm{ph}$ \\
\hline AT5G48880 & peroxisomal 3-keto-acyl-CoA thiolase 2 & ac; nt; ph; ps \\
\hline AT2G33150 & peroxisomal 3-ketoacyl-CoA thiolase 3 & ac; mo; no; nt; ub; ps; sf \\
\hline AT4G14440 & 3-hydroxyacyl-CoA dehydratase 1 & $\mathrm{ph}$ \\
\hline AT3G26820 & Esterase/lipase/thioesterase family & $\mathrm{ph}$ \\
\hline
\end{tabular}

Carbonylation (ca), Lysine Acetylation (ac), Lysine Ubiquitination (ub), Methionine Oxidation (mo), N-glycosylation (ng), N-terminal Acetylation (na), N-terminus Proteolysis (nt), N-terminal Ubiquitination (nu), Phosphorylation (ph), Reversible Cysteine Oxidation (ro), S-Nitrosylation (no), persulfidation (ps), sulfenylation (sf), nitration (ntyr). 


\subsection{Phosphorylation}

Protein phosphorylation, which is a critical step in many signal transduction pathways and a reversible process regulated by kinases and phosphatases, is one of the most important and probably best known protein modification in both prokaryotes and eukaryotes. Phosphorylation mainly takes place on serine, tyrosine, and threonine, with serine being the most common site $(85 \%)$ [113]. Protein kinases transfer the phosphate group from ATP to the hydroxyl group of Ser, Thr, and Tyr residues, while protein phosphatases hydrolyze the phosphoester bond to dephosphorylate proteins [114]. Changes in protein phosphorylation are one of the most common mechanisms used by the cell to regulate the activity, functionality, subcellular location, inter-protein interactions, and turnover of different proteins $[103,114]$. Over recent years, there has been a considerable growth in studies describing different ways of analyzing phosphoproteins: immobilized metal affinity chromatography (IMAC), titanium dioxide metal oxide affinity chromatography (TiO2-MOAC) coupled with mass spectrometric analysis and immunoprecipitation (IP) of tyrosine phosphorylated proteins and peptides with high affinity antiphosphotyrosine antibodies [115]. Thanks to these techniques, a wide-range of proteins have been identified as targets of phosphorylation in several plant tissues and species.

\section{Phosporylated Peroxisomal Proteins}

Phosphoproteomes, kinases, and phosphatases present in Arabidopsis peroxisomes have recently been extensively reviewed [116]. Kataya et al. [116] have gathered information on validated peroxisomal and peroxisome-related proteins, as well as on meta-analysis of phosphoproteins available in the literature to compile a list of almost 100 phosphorylated peroxisomal proteins. Based on these data and those available in Plant PTM Viewer [27], we have reviewed a list of putative peroxisomal phosphoproteins (Table 1 and Table S1). The following kinases have been reported to be associated with peroxisomes: Protein kinases 1, 2, 3, 5, and 6 (PK1,PK2,PK3,PK5,PK6) [117], a protein kinase present in glyoxysomes (GPK1, also called protein kinase 7 (PK7) [118], calcium-dependent protein kinase 1 (CDPK1) [119], and protein kinase constitutive triple response 1 (CTR1), which regulates ethylene signaling suppression [116,120]. Peroxisomal phosphatases include protein phosphatase 2A regulatory (B) subunit ' $\theta$ (PP2A-B' $\theta$ ), purple acid phosphatase 7 (PAR 7), POL-like phosphatase 2 (PLL2), protein phosphatase 2A catalytic (C) subunit 2 (PP2A-C2), protein phosphatase 2A catalytic (C) subunit 5 (PP2A-C5), and protein phosphatase 2A scaffolding (A) subunit 2 (PP2A-A2) (reviewed in [116]).

Protein phosphorylation is involved in the regulation of cross-talk between peroxisomes and other organelles such as in the case of photorespiration (GOX, SAGT1, GGT1, and HPR1) [121] (Table 1 and Table S1). GOX has been reported to be phosphorylated in pea plants exposed to the herbicide 2,4-D [122]. Several enzymes, including ACX4 and ACX6, MFP2, malonyl-CoA decarboxylase family protein, enoyl-CoA hydratase/isomerase, and acetyl-CoA synthetase, involved in different steps in the fatty acid $\beta$-oxidation pathway, are also phosphorylated. The enzymes citrate synthase 1,2 , and 3 , and NAD-malate dehydrogenase 2 are involved in the glyoxylate cycle, while glutathione peroxidase 2, MDHAR 1 and 4, CAT, and SOD are involved in antioxidative defences [116] (Table 1 and Table S1). An increase in SOD3 phosphorylation was observed in pea leaves exposed to the herbicide 2,4-D [122]. Some studies of Arabidopsis plants show that CAT3 is phosphorylated by CPK8 [123] and that CAT3 and CAT2 are phosphorylated by SOS2, a class 3 sucrose-nonfermenting 1-related kinase, and by nucleoside diphosphate kinase 2 (NDPK2), with CAT being activated by phosphorylation mainly under stress conditions [124]. However, as CPK8, SOS2, and NDPK2 are not associated with peroxisomes, CAT may play a role in the cytosol [124]. It has not yet been established that any of the peroxisomal kinases identified play a role in CAT regulation in these organelles, although NDPK1 present in peroxisomes (Table S1) could be involved. In mammalian cells, the tyrosine phosphorylation of CAT is critical for ubiquitination-dependent degradation of this protein [125].

Certain components of the pentose phosphate cycle and NADP-isocitrate dehydrohenase are also found in phosphorylared peroxisomal proteins [116], as well as several proteins involved in amino 
acids and ureide metabolism, peroxisome biogenesis (several PEXs), division/proliferation (PEX11 and DRP), and peroxisomal protein degradation (LON2) [116] (Table 1 and Table S1).

\subsection{Other post-Translational Protein Modifications}

Ubiquitylation is involved in targeting misfolded or unnecessary proteins for proteasome degradation and plays an essential role in cellular responses to stress conditions and in regulating phytohormone signaling [126]. More than 30 peroxisomal proteins to be ubiquitylated have been identified, which include: $\mathrm{NAD}(\mathrm{P}) \mathrm{H}$ dehydrogenases, several kinases, heat shock proteins, zinc finger-related proteins, cytoskeleton-related proteins, $\beta$-oxidation- and glyoxalate cycle-dependent proteins (citrate synthase 3), and antioxidants (APX and CAT) (Table S1). However, the most studied ubiquitinated peroxisomal protein is peroxin5 (PEX5) in S. cerevisiae [127], which is involved in importing peroxisomal proteins through peroxisome biogenesis and in exporting proteins to the cytosol for degradation by the proteasome $[128,129]$. In S. cerevisiae, PEX5 monoubiquitination enables a peroxisome-tethered ATPase complex to recycle PEX5 to the cytosol for further rounds of cargo recruitment, while PEX5 polyubiquitination by the cytosolic UBC4, together with the peroxisomal ubiquitin-protein ligase PEX2, targets PEX5 for proteasomal degradation [127]. Although PEX5 ubiquitination has not yet been demonstrated in plants, mutants defective in peroxisome-associated ubiquitination machinery (pex2-1, pex4, pex10-2, and pex12-1) are involved in plant peroxisomal import and PEX5 retrotranslocation [2].

Protein acetylation is characterized by the attachment of an acetyl group either to the N-terminus of the protein (irreversible modification) or to lysine residues (reversible modification). This modification is dynamically regulated by acyltransferases and deacetylases, although non-enzymatic acetylation by acetyl-CoA and NAD has also been reported [130]. An N-terminal acetyltransferase (AtNatA) has been reported in Arabidopsis, containing catalytic (NAA10) and auxiliary (NAA15) subunits, which is involved in embryogenesis, endosperm development, plant immunity and responses to drought [131]. Nevertheless, our understanding of the physiological effects of acetylation, as well as the overall interplay and regulation of the acetylome itself in plants, remains elusive [132]. In mammalian cells, $\mathrm{Nt}$-acetylation determines the subcellular localization of certain proteins and modulates inter-protein interactions and protein folding [132]. Table 1 and Table S1 show putative acetylated peroxisomal proteins including several antioxidants, proteins involved in $\mathrm{Ca}^{2+}$ homeostasis, fatty acid $\beta$-oxidation, photorespiration, the glyoxylate cycle, $\mathrm{NAD}(\mathrm{P}) \mathrm{H}$ recycling, protein degradation, phosphorylation, and folding, as well as those involved in peroxisome biogenesis and proliferation, stress responses, and hormone biosynthesis. However, these data require experimental confirmation.

Asparagine (N)-linked glycosylation (ALG) of proteins, one of the most common PTMs in plants, is involved in protein folding and stability, secretion and interactions with ligands and other proteins [133]. Thirteen N-glycosylated peroxisomal proteins have been identified in this work (Table 1 and Table S1), some of which are involved in fatty acid $\beta$-oxidation, protein degradation, stress responses and photorespiration.

Peroxisomes contain a large number of N-terminal proteolytic target proteins. These are involved in uric metabolism, fatty acid $\beta$-oxidation, phosphorylation, the glyoxylate cycle, ubiquitination, protein degradation, antioxidant defenses, stress responses, peroxisome biogenesis and proliferation, sulfur metabolism, $\mathrm{NAD}(\mathrm{P}) \mathrm{H}$ recycling, photorespiration, and protein degradation (Table 1 and Table S1).

\section{Crosstalk between PTMs in the Regulation of Peroxisomal Metabolism}

In biological systems, proteins are frequently modified by various PTM events [26]. Computational analysis of proteomes from different organisms has shown that proteins undergoing PTMs engage in more interactions and are positioned in more central locations than non-PTM proteins [26]. Analysis of whole peroxisomal proteomes shows that a very large number of peroxisomal proteins are targeted by multiple PTMs (Table 1 and Table S1), which affect redox balance, the ASC-GSH cycle, photorespiration, 
the glyoxylate cycle, and secondary lipid metabolism (Figure 2, Table 1 and Table S1). PTMs overlap on the same protein more extensively than expected, a pattern commonly observed in different species [26], thus demonstrating the importance of multilevel PTM regulation. This boosts the plasticity of peroxisomes and their capacity to regulate metabolism in response to changes in the environment.

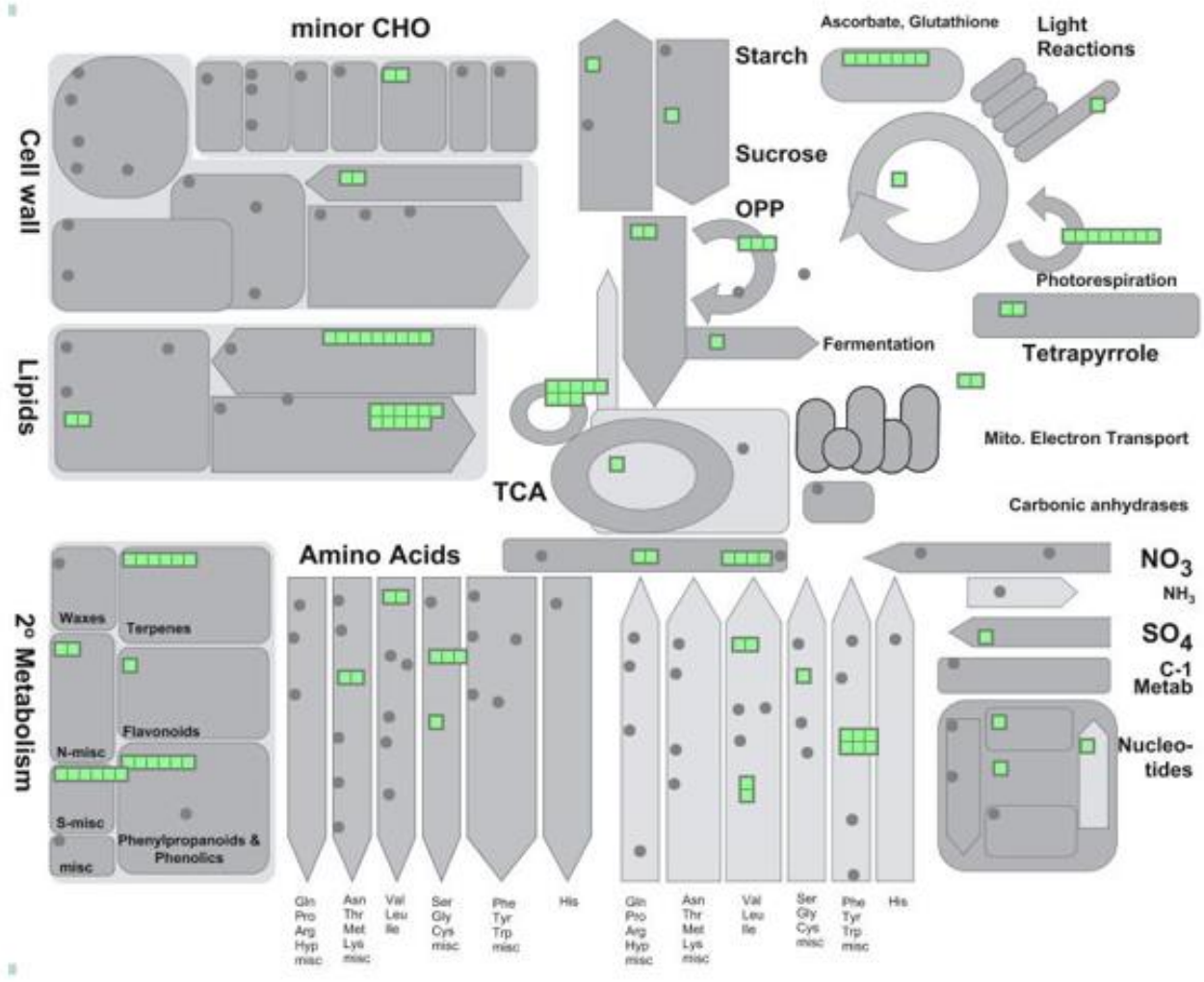

Figure 2. Putative perxisomal protein targets of different PTMs (Table 1 and Table S1) were classified and visualized in metablic pathways using MapMan software (metablism overview; https://mapman. gabipd.org/).

A computational analysis by Duan and Walther [26] revealed that, of the twelve types of PTM studied in mammals, yeast, and Arabidopsis, phosphorylated proteins were most consistently situated in central network locations and most affected by other PTMs. This means that phosphorylation of a single protein potentially modulates many different interactions and molecular processes simultaneously [26]. In plants, protein phosphorylation is an important mechanism involved in regulating $\beta$-oxidation to supply energy and carbon metabolites and to activate the peroxisomal part of the JA biosynthesis pathway (Figure 1; extensively reviewed by [116]). Several key enzymes involved in IAA and SA biosynthetic pathways, which share certain $\beta$-oxidation steps, are known phospho-proteins (Figure 1) [116].

ACX, a key $\beta$-oxidation enzyme, is an important source of $\mathrm{H}_{2} \mathrm{O}_{2}$ in peroxisomes. Six isoenzymes (ACX1-6), which differ with regard to substrate and play distinct overlapping roles in fatty acid oxidation, are present in Arabidopsis [134]. As shown in Table 1, ACX isoforms also differ in relation to their regulation by PTMs; ACX1 is targeted by the largest number of PTMs (S-nitrosylation, nitration, methionine oxidation, phosphorylation, persulfidation, $\mathrm{Nt}$-proteolysis and L-acetylation), while ACX2 is only targeted by $S$-nitrosylation. However, the effect of each PTM on ACX activity has not been established. Recently, CAT2 was reported to physically interact with and increase ACX3 and ACX4 activity in vitro [135]. This interaction may protect ACX enzymes against oxidative $\mathrm{H}_{2} \mathrm{O}_{2}$ degradation and therefore regulate JA biosynthesis, which is essential for plant pathogen defense responses [135]. SA, in turn, suppresses CAT2, leading to an increase in $\mathrm{H}_{2} \mathrm{O}_{2}$ and sulfenylation of tryptophan (Trp) synthetase b subunit 1 (TSB1) located in the chloroplast, thus limiting this precursor 
of auxin synthesis [135]. CAT also interacts with GOX [136], probably as a defense mechanism against oxidative damage.

Although less is known about the effect of S-nitrosylation on $\beta$-oxidation in Arabidopsis, protein $S$-nitrosylation mediated by $S$-nitroso-CoA (SNO-CoA) in yeast and mammalian cells is associated with a specific SNO-CoA reductase encoded by the alcohol dehydrogenase 6 protein [137], which protects acetoacetyl-CoA thiolase against inhibition by S-nitrosylation [137]. However, no presence of SNO-CoA reductase has been reported in plant peroxisomes.

With respect to the interplay between different PTMs, some sulfenylated proteins identified in Arabidopsis are S-glutathionylated, others contain redox-active disulfide bonds, while another group is S-nitrosylated [36]. S-glutathionylation (S-SG) is a ubiquitous redox-sensitive reversible cysteine modification which protects against overoxidation and regulates protein activity [138], while no $S$-glutathionylated peroxisomal proteins have been identified. Interplay between carbonylation, $S$-nitrosylation, and Tyr-nitration has been reported in citrus plants exposed to salinity stress. Under these conditions, $S$-nitrosylation prevents ROS and RNS oxidative damage to several proteins involved in the Calvin-Benson cycle, probably by inducing conformational changes in specific proteins [139]. Cross-talk between $\mathrm{NO}_{2} \mathrm{H}_{2} \mathrm{~S}, \mathrm{ABA}$, and polyamines is involved in acclimation processes in citrus plants (reviewed in [140]). Another example of protection against carbonylation by $S$-nitrosylation is C4 phosphoenolpyruvate carboxylase in sorgum under salinity stress conditions [141]. Some studies also corroborate the protective role played by $S$-nitrosylation in mammalian cells under oxidative stress conditions, which prevents protein carbonylation [72,142].

Other studies demonstrate an antagonistic interplay between protein Tyr nitration and phosphorylation in different biological systems including plants [72,143]. Both these PTMs compete for the same Tyr sites and can therefore interfere with different cellular processes, such as microtubule organization and cell signaling, via MAP kinase cascades [72], although these interactions have not been explored in peroxisomal proteomes. Interestingly, most phosphorylated peroxisomal proteins involved in $\beta$-oxidation do not show nitration, although ACXs and acyl-CoA synthase are $S$-nitrosylated (Table 1 and Table S1). In mammalian cells, S-nitrosylation inhibits phosphorylation-based processes such as signal transduction by inducing conformational changes in kinases or by blocking their autophosphorylation, which affect kinase substrate specificity and selectively modify different protein isoforms [144].

Photorespiration is an important metabolic pathway which facilitates the recycling of 2-phosphoglycolate carbon atoms produced by ribulose-1,5-bisphosphate carboxylase/oxygenase (Rubisco) in the chloroplast, as well as the removal of potentially toxic metabolites. Although different PTMs, shown in Table 1 and Table S1, could modulate most enzymes involved in photorespiration, the regulation of this cycle is little understood. Protein phosphorylation, which commonly occurs in photorespiration enzymes [121], appears to be a highly complex process due to the possible interplay of different PTMs such as S-nitrosylation, nitration, persulfidation, and acetylation (Table 1). The contribution of each PTM to the regulation of this pathway depends on the redox environment inside the peroxisome. CAT, SOD, DHAR, MDHAR, APX, and GPX, the main enzymes involved in antioxidant defenses in peroxisomes, are also targets of different PTMs (Table 1), which facilitate finely tuned regulation of ROS levels to regulate redox signaling and protection of other proteins against oxidative damage.

Peroxisomal dynamics can be regulated by multiple PTMs. Thus, as mentioned previously in yeast and human fibroblasts, PEX5 redox changes regulate peroxisomal biogenesis by controlling the import of peroxisomal matrix proteins [2], although this has not been demonstrated in plants. As shown in Table S1, most PEXs are targeted only by phosphorylation, except PEX14, which is targeted acetylation and $\mathrm{N}$-terminus proteolysis, and pPEX19 which is also $S$-nitrosylated. Interestingly, PEX11 phosphorylation is an important issue in P pastoris for peroxisome division [145]. Organelle degradation by autophagy in yeast and mammalian cells is regulated by multiple, mutually exclusive PTMs, such as acetylation, phosphorylation and ubiquitilation, which target the same lysine and 
thus provide opportunities for cross-regulation [146]. Although not fully understood in plants, the mechanism involved in the regulation of pexophagy by PTMs is triggered by redox changes and protein carbonylation $[22,23,51]$. While several PEXs have been reported to be phosphorylated in Arabidopsis (Table S1), a direct relationship between ROS, PEX, phosphorylation, and pexophagy has not been established. In the methylotrophic yeast Hansenula polymorpha, phosphorylated PEX14p proteins are needed for pexophagy, while nonphosphorylated proteins are involved in protein import [147]. Peroxisomal quality control could also be regulated by the PTM cross-talk of proteases such as LON2 which can be regulated by $\mathrm{N}$-terminus proteolysis, $\mathrm{N}$-acetylation, and phosphorylation (Table S1). The formation of peroxisomal extensions (peroxules) is regulated by ROS and PEX11a [7], although no redox-dependent PTMs of this protein have been reported. However, as previously mentioned, PEX11a, PEX11c, and PEX11b are identified in this review as targets of phosphorylation, while PEX11d is also acetylated and nitrated, suggesting that these PTMs on PEX11 may play an important role in peroxisomal biogenesis and inter-organelle communication.

\section{Conclusions}

Peroxisomes, which are essential for plant development and stress responses, are characterized by considerable metabolic plasticity and act as a redox metabolism and signaling hub. This plasticity depends on a complex network of PTMs which regulate essential metabolic pathways, hormone balance, and inter-organelle cross-talk. However, further functional studies of the role played by most of the PTMs studied in each protein's activity and degradation, and in the interplay and hierarchy of the different PTMs in peroxisomes, are required.

Supplementary Materials: The following are available online at http://www.mdpi.com/1422-0067/20/19/4881/s1.

Author Contributions: C.G. and L.C.R. reviewed and wrote the text regarding persulfidation; M.C.R.-P. reviewed and wrote the text regarding the NO-related PTMs, collected the peroxisomal proteins from different databases and created Figure 1, Table 1 and Table S1. L.M.S. defined the focus of the review, coordinated contributions, wrote the manuscript and reviewed studies of $\mathrm{H}_{2} \mathrm{O}_{2}$-dependent PTMs, phosphorylation, other PTMs and inter-PTM cross-talk.

Funding: This study was co-funded by ERDF (UE) and the Spanish Ministry of Science, Innovation and Universities grants PGC2018-098372-B-I00 and BIO2016-76633-P.

Acknowledgments: The authors wish to thank Michael O'Shea for proofreading the manuscript.

Conflicts of Interest: The authors declare no conflict of interest.

\section{References}

1. Sandalio, L.M.; Romero-Puertas, M.C. Peroxisomes sense and respond to environmental cues by regulating ROS and RNS signalling networks. Annals Bot. 2015, 116, 475-485. [CrossRef] [PubMed]

2. Kao, Y.T.; Gonzalez, K.L.; Bartel, B. Peroxisome function, biogenesis, and dynamics in plants. Plant Physiol. 2018, 176, 162-177. [CrossRef] [PubMed]

3. Reumann, S.; Bartel, B. Plant peroxisomes: Recent discoveries in functional complexity, organelle homeostasis, and morphological dynamics. Curr. Opin. Plant Biol. 2016, 34, 17-26. [CrossRef] [PubMed]

4. Ortega-Galisteo, A.P.; Rodríguez-Serrano, M.; Pazmiño, D.M.; Gupta, D.K.; Sandalio, L.M.; and Romero-Puertas, M.C. S-Nitrosylated proteins in pea (Pisum sativum L.) leaf peroxisomes: Changes under abiotic stress. J. Exp. Bot. 2012, 63, 2089-2103. [CrossRef] [PubMed]

5. Kataya, A.R.; Heidari, B.; Hagen, L.; Kommedal, R.; Slupphaug, G.; Lillo, C. Protein phosphatase 2A holoenzyme is targeted to peroxisomes by piggybacking and positively affects peroxisomal $\beta$-oxidation. Plant Physiol. 2015, 167, 493-506. [CrossRef] [PubMed]

6. Hu, J. Molecular basis of peroxisome division and proliferation in plants. Int. Rev. Cell Mol. Biol. 2010, 279, 79-99. [PubMed]

7. Rodríguez-Serrano, M.; Romero-Puertas, M.C.; Sanz-Fernández, M.; Hu, J.; Sandalio, L.M. Peroxisomes extend peroxules in a fast response to stress via a reactive oxygen species-mediated induction of the peroxin PEX11a. Plant Physiol. 2016, 171, 1665-1674. [CrossRef] [PubMed] 
8. Aung, K.; Hu, J. Differential roles of Arabidopsis dynamin-related proteins DRP3A, DRP3B, and DRP5B in organelle division. J. Integr. Plant Biol. 2012, 54, 921-931.

9. Goepfert, S.; Poirier, Y. $\beta$-Oxidation in fatty acid degradation and beyond. Cur. Opin. Plant Biol. 2007, 10, 245-251. [CrossRef] [PubMed]

10. Pan, R.; Liu, J.; Hu, J. Peroxisomes in plant reproduction and seed-related development. J. Int. Plant Biol 2019, 61, 784-802. [CrossRef]

11. Cornah, J.E.; Smith, S.M. Synthesis and function of glyoxylate cycle enzymes. In Plant Peroxisomes; Baker, A., Graham, L.A., Eds.; Elsevier Academic Publishers: Dordrecht, The Netherlands, 2002; pp. 57-101.

12. Widhalm, J.R.; Dudareva, N. A familiar ring to it: Biosynthesis of plant benzoic acids. Mol. Plant 2015, 8, 83-97. [CrossRef] [PubMed]

13. Adebesin, F.; Widhalm, J.R.; Lynch, J.H.; McCoy, R.M.; Dudareva, N. A peroxisomal thioesterase plays auxiliary roles in plant $\beta$-oxidative benzoic acid metabolism. Plant J. 2018, 93, 905-916. [CrossRef] [PubMed]

14. Dellero, Y.; Jossier, M.; Schmitz, J.; Maurino, V.G.; Hodges, M. Photorespiratory glycolate-glyoxylate metabolism. J. Exp. Bot. 2016, 67, 3041-3052. [CrossRef] [PubMed]

15. Farmer, L.M.; Rinaldi, M.A.; Young, P.G.; Danan, C.H.; Burkhart, S.E.; Bartel, B. Disrupting autophagy restores peroxisome function to an Arabidopsis lon2 mutant and reveals a role for the LON2 protease in peroxisomal matrix protein degradation. Plant Cell 2013, 25, 4085-4100. [CrossRef] [PubMed]

16. Goto-Yamada, S.; Mano, S.; Nakamori, C.; Kondo, M.; Yamawaki, R.; Kato, A.; Nishimura, M. Chaperone and protease functions of LON protease 2 modulate the peroxisomal transition and degradation with autophagy. Plant Cell Physiol. 2014, 55, 482-496. [CrossRef] [PubMed]

17. Del Rio, L.A.; Pastori, G.M.; Palma, J.M.; Sandalio, L.M.; Sevilla, F.; Corpas, F.J.; Jimenez, A.; Lopez-Huertas, E.; Hernandez, J.A. The activated oxygen role ofperoxisomes in senescence. Plant Physiol. 1998, 116, 1195-1200. [CrossRef]

18. Rodríguez-Serrano, M.; Romero-Puertas, M.C.; Sparkes, I.; Hawes, C.; del Río, L.A.; Sandalio, L.M. Peroxisome dynamics in Arabidopsis plants under oxidative stress induced by cadmium Free Radic. Biol. Med. 2009, $47,1632-1639$.

19. Sinclair, A.M.; Trobacher, C.P.; Mathur, N.; Greenwood, J.S.; Mathur, J. Peroxule extension over ER-defined paths constitutes a rapid subcellular response to hydroxyl stress. Plant J. 2009, 59, 231-242. [CrossRef]

20. Ma, C.; Hagstrom, D.; Polley, S.G.; Subramani, S. Redox-regulated cargo binding and release by the peroxiosomal targeting signal receptor, Pex5. J. Biol. Chem. 2013, 288, 27220-27231. [CrossRef]

21. Apanasets, O.; Grou, C.P.; Van Veldhoven, P.P.; Brees, C.; Wang, B.; Nordgren, M.; Dodt, G.; Azevedo, J.E.; Fransen, M. PEX5, the shuttling import receptor for peroxisomal matrix proteins, is a redox-sensitive protein. Traffic 2014, 15, 94-103. [CrossRef]

22. Yoshimoto, K.; Shibata, M.; Kondo, M.; Oikawa, K.; Sato, M.; Toyooka, K.; Shirasu, K.; Nishimura, M.; Ohsumi, Y. Organ-specific quality control of plant peroxisomes is mediated by autophagy. J. Cell Sci. 2014, 127, 1161-1168. [CrossRef] [PubMed]

23. Calero-Muñoz, N.; Exposito-Rodriguez, M.; Collado-Arenal, A.M.; Rodríguez-Serrano, M.; Laureano-Marín, A.M.; Santamaría, M.E.; Gotor, C.; Díaz, I.; Mullineaux, P.M.; Romero-Puertas, M.C.; et al. Cadmium induces reactive oxygen species dependent pexophagy in Arabidopsis leaves. Plant Cell Environ. 2019. [CrossRef] [PubMed]

24. Voitsekhovskaja, O.V.; Schiermeyer, A.; Reumann, S. Plant peroxisomes are degraded by starvation-induced and constitutive autophagy in tobacco BY-2 suspension-cultured cells. Front. Plant Sci. 2014, 5, 629. [CrossRef] [PubMed]

25. Hashiguchi, A.; Komatsu, S. Impact of post-translational modifications of crop proteins under abiotic stress. Proteomes 2016, 4, 42. [CrossRef] [PubMed]

26. Duan, G.; Walther, D. The Roles of Post-translational Modifications in the Context of Protein Interaction Networks. PLoS Comput. Biol. 2015, 11, e1004049. [CrossRef] [PubMed]

27. Plant PTM Viewer. Available online: http://www.psb.ugent.be/webtools/ptm-viewer/index.php (accessed on 11 June 2019).

28. The Arabidopsis Information Resource. Available online: https://www.arabidopsis.org (accessed on 11 June 2019).

29. NCBI. Available online: https://www.ncbi.nlm.nih.gov/protein (accessed on 11 June 2019).

30. Pan, R.; Hu, J. Proteome of plant peroxisome. In Proteomics of peroxisomes: Identifying Novel Functions and Regulatory Networks; Del Rñío, L.A., Schrader, M., Eds.; Springer: Singapore, 2018; pp. 3-46. 
31. Venny Tool. Available online: http://bioinfogp.cnb.csic.es/tools/venny/ (accessed on 25 August 2019).

32. Young, D.; Pedre, B.; Ezerinxa, D.; De Smet, B.; Lewandowska, A.; Tossounian, M.A.; Bodra, N.; Huang, J.; Astolfi-Rosado, L.; Van Breusegem, F.; et al. Protein Promiscuity in $\mathrm{H}_{2} \mathrm{O}_{2}$. Antioxid. Redox Sign. 2019, 30, 1285-1324. [CrossRef]

33. Huang, J.; Willemsd, P.; Van Breusegemd, F.; Messens, J. Pathways crossing mammalian and plant sulfenomic landscapes. Free Radic. Biol. Med. 2018, 122, 193-201. [CrossRef] [PubMed]

34. Pye, V.E.; Christensen, C.E.; Dyer, J.H.; Arent, S.; Henriksen, A. Peroxisomal plant 3-ketoacyl-coa thiolase structure and activity are regulated by a sensitive redox switch. J. Biol. Chem. 2010, 285, 24078-24088. [CrossRef]

35. Waszczak, C.; Akter, S.; Eeckhout, D.; Persiau, G.; Wahni, K.; Bodra, N.; Van Molle, I.; De Smet, B.; Vertommen, D.; Gevaert, K.; et al. Sulfenome mining in Arabidopsis thaliana. Proc. Natl. Acad. Sci. USA 2014, 111, 11545-11550. [CrossRef]

36. Akter, S.; Carpentierg, S.; Van Breusegem, F.; Messens, J. Identification of dimedone-trapped sulfenylated proteins in plants under stress. Biochem. Biophys. Rep. 2017, 9, 106-113. [CrossRef]

37. Poole, L.B.; Karplus, P.A.; Claiborne, A. Protein sulfenic acids in redox signaling. Annu. Rev. Pharmacol. Toxicol. 2004, 44, 325-347. [CrossRef]

38. Schmitz, J.; Rossoni, A.W.; Maurino, V.G. Dissecting the physiological function of plant glyoxalase I and glyoxalase I-like proteins. Front. Plant. Sci. 2018, 9, 1618. [CrossRef]

39. Rao, R.S.; Møller, I.M. Pattern of occurrence and occupancy of carbonylation sites in proteins. Proteomics 2011, 11, 4166-4173. [CrossRef]

40. Halliwell, B.; Gutteridge, J.M.C. Free Radicals in Biology and Medicine, 4th ed.; Oxford University Press: New York, NY, USA, 2007.

41. Wong, C.M.; Marcocci, L.; Liu, L.; Suzuki, Y.J. Cell signaling by protein carbonylation and decarbonylation. Antioxid Redox Signal. 2010, 12, 393-404. [CrossRef]

42. Romero-Puertas, M.C.; Palma, J.M.; Gómez, M.; Del Río, L.A.; Sandalio, L.M. Cadmium causes the oxidative modification of proteins in pea plants. Plant Cell Environ. 2002, 25, 677-686. [CrossRef]

43. Nyström, T. Role of oxidative carbonylation in protein quality control and senescence. EMBO J. 2005, 24, 1311-1317. [CrossRef]

44. Lounifi, I.; Arc, E.; Molassiotis, A.; Job, D.; Rajjou, L.; Tanou, G. Interplay between protein carbonylation and nitrosylation in plants. Proteomics 2013, 13, 568-578. [CrossRef]

45. Polge, C.; Jaquinod, M.; Holzer, F.; Bourguignon, J.; Walling, L.; Brouquisse, R. Evidence for the existence in Arabidopsis thaliana of the proteasome proteolytic pathway: Activation in response to cadmium. J. Biol Chem. 2009, 284, 35412-35424. [CrossRef]

46. Xiong, Y.; Contento, A.L.; Nguyen, P.Q.; Bassham, D.C. Degradation of oxidized proteins by autophagy during oxidative stress in Arabidopsis. Plant Physiol. 2007, 143, 291-299. [CrossRef]

47. Wehr, N.B.; Levine, R.L. Quantification of protein carbonylation. In Cell Senescence: Methods and Protocols, Methods in Molecular Biology; Galluzzi, L., Vitale, I., Kepp, O., Kroemer, G., Eds.; Humana: Louisville, KY, USA, 2013; pp. 265-281.

48. Mano, J.; Nagata, M.; Okamura, S.; Shiraya, T.; Mitsui, T. Identification of oxidatively modified proteins in salt-stressed arabidopsis: A carbonyl-targeted proteomics approach. Plant Cell Physiol. 2014, 55, 1233-1244. [CrossRef]

49. Weber, D.; Davies, M.J.; Grune, T. Determination of protein carbonyls in plasma, cell extracts, tissue homogenates, isolated proteins: Focus on sample preparation and derivatization conditions. Redox Biol. 2015, 5, 367-380. [CrossRef]

50. Nguyen, A.T.; Donaldson, R.P. Metal-catalyzed oxidation induces carbonylation of peroxisomal proteins and loss of enzymatic activities. Arch. Biochem. Biophys. 2005, 439, 25-31. [CrossRef]

51. Shibata, M.; Oikawa, K.; Yoshimoto, K.; Kondo, M.; Mano, S.; Yamada, K.; Hayashi, M.; Sakamoto, W.; Ohsumi, Y.; Nishimura, M. Highly oxidized peroxisomes are selectively degraded via autophagy in Arabidopsis. Plant Cell 2013, 25, 4967-4983. [CrossRef]

52. Sanz, L.; Albertos, P.; Mateos, I.; Sánchez-Vicente, I.; Lechón, T.; Fernández Marcos, M.; Lorenzo, O. Nitric oxide (NO) and phytohormones crosstalk during early plant development. J. Exp. Bot. 2015, 66, 2857-2868. [CrossRef] 
53. Castillo, M.C.; Coego, A.; Costa-Broseta, Á.; León, J. Nitric oxide responses in Arabidopsis hypocotyls are mediated by diverse phytohormone pathways. J. Exp. Bot. 2018, 69, 5265-5278. [CrossRef]

54. Trapet, P.; Kulik, A.; Lamotte, O.; Jeandroz, S.; Bourque, S.; Nicolas-Francès, V.; Rosnoblet, C.; Besson-Bard, A.; Wendehenne, D. NO signaling in plant immunity: A tale of messengers. Phytochemistry 2015, 112, 72-79. [CrossRef]

55. Gupta, K.J.; Igamberdiev, A.U. Reactive nitrogen species in mitochondria and their implications in plant energy status and hypoxic stress tolerance. Front. Plant Sci. 2016, 7,1-6. [CrossRef]

56. Terrón-Camero, L.C.; Peláez-Vico, M.A.; Del Val, C.; Sandalio, L.M.; Romero-Puertas, M.C. Role of nitric oxide in plant responses to heavy metal stress: Exogenous application versus endogenous production. J. Exp. Bot. 2019, 70, 4477-4488. [CrossRef]

57. Martínez-Ruiz, A.; Lamas, S. S-Nitrosylation: A potential new paradigm in signal transduction. Cardiovasc. Res. 2004, 62, 43-52. [CrossRef]

58. Janssen-Heininger, Y.M.; Mossman, B.T.; Heintz, N.H.; Forman, H.J.; Kalyanaraman, B.; Finkel, T.; Stamler, J.S.; Rhee, S.G.; van der Vliet, A. Redox-based regulation of signal transduction: Principles, pitfalls, and promises. Free Radic. Biol. Med. 2008, 45, 1-17. [CrossRef]

59. Martínez-Ruiz, A.; Araújo, I.M.; Izquierdo-Álvarez, A.; Hernansanz-Agustín, P.; Lamas, S.; Serrador, J.M. Specificity in S-Nitrosylation: A Short-Range Mechanism for NO Signaling? Antioxid. Redox Signal. 2013, 19, 1220-1235. [CrossRef]

60. Romero-Puertas, M.C.; Rodríguez-Serrano, M.; Sandalio, L.M. Protein S-nitrosylation in plants under abiotic stress: An overview. Front. Plant Sci. 2013, 4, 373. [CrossRef]

61. Spoel, S.H.; Tada, Y.; Loake, G.J. Post-translational protein modification as a tool for transcription reprogramming. New Phytol. 2010, 186, 333-339. [CrossRef]

62. Cui, J.L.; Wang, Y.N.; Jiao, J.; Gong, Y.; Wang, J.H.; Wang, M.L. Fungal endophyte-induced salidroside and tyrosol biosynthesis combined with signal cross-talk and the mechanism of enzyme gene expression in Rhodiola crenulata. Sci. Rep. 2017, 7, 1-9. [CrossRef]

63. Mengel, A.; Ageeva, A.; Georgii, E.; Bernhardt, J.; Wu, K.; Durner, J.; Lindermayr, C. Nitric oxide modulates histone acetylation at stress genes by inhibition of histone deacetylases. Plant Physiol. 2016, 173, 1434-1452. [CrossRef]

64. Simontacchi, M.; García-Mata, C.; Bartoli, C.G.; Santa-María, G.E.; Lamattina, L. Nitric oxide as a key component in hormone-regulated processes. Plant Cell Rep. 2013, 32, 853-866. [CrossRef]

65. Gibbs, D.J.; Md Isa, N.; Movahedi, M.; Lozano-Juste, J.; Mendiondo, G.M.; Berckhan, S.; Marín-de la Rosa, N.; Conde, J.V.; Correia, C.S.; Pearce, S.P.; et al. Nitric oxide sensing in plants is mediated by proteolytic control of group vii erf transcription factors. Mol. Cell 2014, 53, 369-379. [CrossRef]

66. Albertos, P.; Romero-Puertas, M.C.; Tatematsu, K.; Mateos, I.; Sánchez-Vicente, I.; Nambara, E.; Lorenzo, O. S-nitrosylation triggers ABI5 degradation to promote seed germination and seedling growth. Nat. Commun. 2015, 6, 8669. [CrossRef]

67. Romero-Puertas, M.C.; Sandalio, L.M. Role of NO-dependent posttranslational modifications in switching metabolic pathways. Adv. Bot Res. 2016, 77, 123-144.

68. Serrato, A.J.; Romero-Puertas, M.C.; Lázaro-Payo, A.; Sahrawy, M. Regulation by S-nitrosylation of the Calvin-Benson cycle fructose-1,6-bisphosphatase in Pisum sativum. Redox Biol. 2018, 14, 409-416. [CrossRef]

69. Hu, J.; Huang, X.; Chen, L.; Sun, X.; Lu, C.; Zhang, L.; Wang, Y.; Zuo, J. Site-Specific nitrosoproteomic identification of endogenously s -nitrosylated proteins in Arabidopsis. Plant Physiol. 2015, 167, 1731-1746. [CrossRef] [PubMed]

70. Kovacs, I.; Lindermayr, C. Nitric oxide-based protein modification: Formation and site-specificity of protein S-nitrosylation. Front. Plant. Sci. 2013, 4, 1-10. [CrossRef] [PubMed]

71. Astier, J.; Kulik, A.; Koen, E.; Besson-Bard, A.; Bourque, S.; Jeandroz, S.; Lamotte, O.; Wendehenne, D. Protein S-nitrosylation: What's going on in plants? Free Radic. Biol. Med. 2012, 53, 1101-1110. [CrossRef]

72. Arasimowicz-Jelonek, M.; Floryszak-Wieczorek, J. A physiological perspective on targets of nitration in NO-based signalling networks in plants. J. Exp. Bot. 2019, 70, 4379-4389. [CrossRef] [PubMed]

73. Chaki, M.; Álvarez de Morales, P.; Ruiz, C.; Begara-Morales, J.C.; Barroso, J.B.; Corpas, F.J.; Palma, J.M. Ripening of pepper (Capsicum annuum) fruit is characterized by an enhancement of protein tyrosine nitration. Ann. Bot. 2015, 116, 637-647. [CrossRef] 
74. Lozano-Juste, J.; Colom-Moreno, R.; León, J. In vivo protein tyrosine nitration in Arabidopsis thaliana. J. Exp. Bot. 2011, 62, 3501-3517. [CrossRef] [PubMed]

75. Vandelle, E.; Delledonne, M. Peroxynitrite formation and function in plants. Plant Sci. 2011, 181, 534-539. [CrossRef]

76. Martínez-Ruiz, A.; Lamas, S. Two decades of new concepts in nitric oxide signaling: From the discovery of a gas messenger to the mediation of nonenzymatic posttranslational modifications. IUBMB Life 2009, 61, 91-98. [CrossRef]

77. Perazzolli, M.; Dominici, P.; Romero-Puertas, M.C.; Zago, E.; Zeier, J.; Sonoda, M.; Lamb, C.; Delledonne, M. Nonsymbiotic hemoglobin AHb1 modulates nitric oxide bioactivity in Arabidopsis thaliana. Plant Cell 2004, 16, 2785-2794. [CrossRef]

78. Igamberdiev, A.U.; Bykova, N.V.; Hill, R.D. Nitric oxide scavenging by barley hemoglobin is facilitated by a monodehydroascorbate reductase-mediated ascorbate reduction of methemoglobin. Planta 2006, 223, 1033-1040. [CrossRef]

79. Smagghe, B.J.; Trent, I.I.I.J.T.; Hargrove, M.S. NO dioxygenase activity in hemoglobins is ubiquitous in vitro, but limited by reduction in vivo. PLoS ONE 2008, 3, e2039. [CrossRef] [PubMed]

80. Calvo-Begueria, L.; Cuypers, B.; Van Doorslaer, S.; Abbruzzetti, S.; Bruno, S.; Berghmans, H.; Dewilde, S.; Ramos, J.; Viappiani, C.; Becana, M. Characterization of the heme pocket structure and ligand binding kinetics of non-symbiotic hemoglobins from the model legume Lotus japonicus. Front. Plant. Sci. 2017, 8, 407. [CrossRef]

81. Prado, A.M.; Porterfield, D.M.; Feijó, J.A. Nitric oxide is involved in pollen tube growth regulation and re-orientation of pollen tubes. Development 2004, 131, 2707-2714. [CrossRef] [PubMed]

82. Corpas, F.J.; Barroso, J.B.; Carreras, A.; Quirós, M.; León, A.M.; Romero-Puertas, M.C.; Esteban, F.J.; Valderrama, R.; Palma, J.M.; Sandalio, L.M.; et al. Cellular and subcellular localization of endogenous nitric oxide in young and senescent pea plants. Plant Physiol. 2004, 136, 2722-2733. [CrossRef] [PubMed]

83. Del Río, L.A. Peroxisomes as a cellular source of reactive nitrogen species signal molecules. Arch. Biochem. Biophys. 2011, 506, 1-11. [CrossRef] [PubMed]

84. Astier, J.; Gross, I.; Durner, J. Nitric oxide production in plants: An update. J. Exp. Bot. 2018, 69, 3401-3411. [CrossRef]

85. Godber, B.L.J.; Doel, J.J.; Durgan, J.; Eisenthal, R.; Harrison, R.A. A new route to peroxynitrite: A role for xanthine oxidoreductase A new route to peroxynitrite: A role for xanthine oxidoreductase. FEBS Lett. 2000, 475, 93-96. [CrossRef]

86. Corpas, F.J.; Barroso, J.B. Peroxynitrite (ONOO-) is endogenously produced in Arabidopsis peroxisomes and is overproduced under cadmium stress. Ann. Bot. 2014, 113, 87-96. [CrossRef]

87. Fares, A.; Rossignol, M.; Peltier, J.-B. Proteomics investigation of endogenous S-nitrosylation inArabidopsis. Biochem. Biophys. Res. Comm. 2011, 416, 331-336. [CrossRef]

88. Puyaubert, J.; Fares, A.; Rézé, N.; Peltier, J.-B.; Baudouin, E. Identification of endogenously S-nitrosylated proteins in Arabidopsis plantlets: Effect of cold stress on cysteine nitrosylation level. Plant Sci. 2014, 215, 150-156. [CrossRef]

89. Morisse, S.; Zaffagnini, M.; Gao, X.-H.; Lemaire, S.D.; Marchand, C.H. Insight into protein S-nitrosylation in Chlamydomonas reinhardtii. Antioxid. Redox Signal. 2014, 21, 1271-1284. [CrossRef] [PubMed]

90. Holzmeister, C.; Gaupels, F.; Geerlof, A.; Sarioglu, H.; Sattler, M.; Durner, J.; Lindermayr, C. Differential inhibition of Arabidopsis superoxide dismutases by peroxynitrite-mediated tyrosine nitration. J. Exp. Bot. 2015, 66, 989-999. [CrossRef] [PubMed]

91. Begara-Morales, J.C.; Sánchez-Calvo, B.; Chaki, M.; Mata-Pérez, C.; Valderrama, R.; Padilla, M.N.; López-Jaramillo, J.; Luque, F.; Corpas, F.J.; Barroso, J.B. Differential molecular response of monodehydroascorbate reductase and glutathione reductase by nitration and S-nitrosylation. J. Exp. Bot. 2015, 66, 5983-5996. [CrossRef] [PubMed]

92. Gotor, C.; Laureano-Marín, A.M.; Arenas-Alfonseca, L.; Moreno, I.; Aroca, A.; García, I.; Romero, L.C. Advances in Plant Sulfur Metabolism and Signaling. In Progress in Botany. Cánovas; Lüttge, U., Matyssek, R., Eds.; Springer: Cham, Switzerland, 2017; pp. 45-66.

93. Hancock, J.T. Hydrogen sulfide and environmental stresses. Environ. Exp. Bot. 2019, 161, 50-56. [CrossRef]

94. Li, Z.-G.; Min, X.; Zhou, Z.-H. Hydrogen Sulfide: A signal molecule in plant cross-adaptation. Front. Plant. Sci. 2016, 7, 1621. [CrossRef] [PubMed] 
95. Gotor, C.; Garcia, I.; Aroca, A.; Laureano-Marin, A.M.; Arenas-Alfonseca, L.; Jurado-Flores, A.; Moreno, I.; Romero, L.C. Signaling by hydrogen sulfide and cyanide through posttranslational modification. J. Exp. Bot. 2019, 70, 4251-4265. [CrossRef]

96. Chen, J.; Wu, F.H.; Wang, W.H.; Zheng, C.J.; Lin, G.H.; Dong, X.J.; He, J.X.; Pei, Z.M.; Zheng, H.L. Hydrogen sulphide enhances photosynthesis through promoting chloroplast biogenesis, photosynthetic enzyme expression, and thiol redox modification in Spinacia oleracea seedlings. J. Exp. Bot. 2011, 62, 4481-4493. [CrossRef]

97. Xie, Y.; Zhang, C.; Lai, D.; Sun, Y.; Samma, M.K.; Zhang, J.; Shen, W. Hydrogen sulfide delays GA-triggered programmed cell death in wheat aleurone layers by the modulation of glutathione homeostasis and heme oxygenase-1 expression. J. Plant. Physiol. 2014, 171, 53-62. [CrossRef]

98. Gotor, C.; Garcia, I.; Crespo, J.L.; Romero, L.C. Sulfide as a signaling molecule in autophagy. Autophagy 2013, 9, 609-611. [CrossRef]

99. Laureano-Marin, A.M.; Moreno, I.; Aroca, Á.; García, I.; Romero, L.C.; Gotor, C. Regulation of Autophagy by Hydrogen Sulfide. In Gasotransmitters in Plants: The Rise of a New Paradigm in Cell Signaling; Lamattina, L., García-Mata, C., Eds.; Springer: Cham, Switzerland, 2016; pp. 53-75.

100. Jin, Z.; Xue, S.; Luo, Y.; Tian, B.; Fang, H.; Li, H.; Pei, Y. Hydrogen sulfide interacting with abscisic acid in stomatal regulation responses to drought stress in Arabidopsis. Plant Physiol. Biochem. 2013, 62, 41-46. [CrossRef]

101. Scuffi, D.; Álvarez, C.; Laspina, N.; Gotor, C.; Lamattina, L.; García-Mata, C. Hydrogen sulfide generated by l-cysteine desulfhydrase acts upstream of nitric oxide to modulate abscisic acid-dependent stomatal closure. Plant Physiol. 2014, 166, 2065-2076. [CrossRef] [PubMed]

102. Papanatsiou, M.; Scuffi, D.; Blatt, M.R.; García-Mata, C. Hydrogen sulfide regulates inward-rectifying k+ channels in conjunction with stomatal closure. Plant Physiol. 2015, 168, 29-35. [CrossRef] [PubMed]

103. Wang, L.; Wan, R.; Shi, Y.; Xue, S. Hydrogen sulfide activates s-type anion channel via ost1 and Ca(2+) modules. Mol. Plant 2016, 9, 489-491. [CrossRef] [PubMed]

104. Scuffi, D.; Nietzel, T.; Di Fino, L.M.; Meyer, A.J.; Lamattina, L.; Schwarzländer, M.; Laxalt, A.M.; García-Mata, C. Hydrogen sulfide increases production of NADPH oxidase-dependent hydrogen peroxide and phospholipase d-derived phosphatidic acid in guard cell signaling. Plant Physiol. 2018, 176, 2532-2542. [CrossRef] [PubMed]

105. Filipovic, M.R.; Zivanovic, J.; Alvarez, B.; Banerjee, R. Chemical biology of H2S signaling through persulfidation. Chem. Rev. 2018, 118, 1253-1337. [CrossRef]

106. Aroca, A.; Gotor, C.; Romero, L.C. Hydrogen Sulfide Signaling in Plants: Emerging Roles of Protein Persulfidation. Front. Plant. Sci. 2018, 9, 1369. [CrossRef]

107. Aroca, A.; Benito, J.M.; Gotor, C.; Romero, L.C. Persulfidation proteome reveals the regulation of protein function by hydrogen sulfide in diverse biological processes in Arabidopsis. J. Exp. Bot. 2017, 68, 4915-4927. [CrossRef]

108. Aroca, Á.; Serna, A.; Gotor, C.; Romero, L.C. S-Sulfhydration: A cysteine posttranslational modification in plant systems. Plant Physiol. 2015, 168, 334-342. [CrossRef]

109. Aroca, A.; Schneider, M.; Scheibe, R.; Gotor, C.; Romero, L.C. Hydrogen sulfide regulates the cytosolic/nuclear partitioning of glyceraldehyde-3-phosphate dehydrogenase by enhancing its nuclear localization. Plant Cell Physiol. 2017, 58, 983-992. [CrossRef]

110. Corpas, F.J.; Barroso, J.B.; Gonzalez-Gordo, S.; Munoz-Vargas, M.A.; Palma, J.M. Hydrogen sulfide: A novel component in Arabidopsis peroxisomes which triggers catalase inhibition. J. Integr. Plant Biol. 2019, 61, 871-883. [CrossRef]

111. Munoz-Vargas, M.A.; Gonzalez-Gordo, S.; Palma, J.M.; Corpas, F.J. Inhibition of NADP-malic enzyme activity by $\mathrm{H} 2 \mathrm{~S}$ and $\mathrm{NO}$ in sweet pepper (Capsicum annuum L.) fruits. Physiol. Plant 2019. [CrossRef]

112. Munoz-Vargas, M.A.; Gonzalez-Gordo, S.; Canas, A.; Lopez-Jaramillo, J.; Palma, J.M.; Corpas, F.J. Endogenous hydrogen sulfide (H2S) is up-regulated during sweet pepper (Capsicum annuum L.) fruit ripening. In vitro analysis shows that NADP-dependent isocitrate dehydrogenase (ICDH) activity is inhibited by H2S and NO. Nitric. Oxide 2018, 81, 36-45. [CrossRef] [PubMed]

113. de la Fuente van Bentem, S.; Anrather, D.; Roitinger, E.; Djamei, A.; Hufnag, T.; Barta, A.; Csaszar, E.; Dohnal, I.; Lecourieux, D.; Hirt, H. Phosphoproteomics reveals extensive in vivo phosphorylation of Arabidopsis proteins involved in RNA metabolism. Nucleic. Acids Res. 2006, 34, 3267-3278. [CrossRef] [PubMed] 
114. Lillo, C.; Kataya, A.R.; Heidari, B.; Creighton, M.T.; Nemie-Feyissa, D.; Ginbot, Z.; Jonassen, E.M. Protein phosphatases PP2A, PP4 and PP6: Mediators and regulators in development and responses to environmental cues. Plant Cell Environ. 2014, 37, 2631-2648. [CrossRef] [PubMed]

115. Cheng, L.C.; Li, Z.; Graeber, T.G.; Graham, N.A.; Drake, J.M. Phosphopeptide enrichment coupled with label-free quantitative mass spectrometry to investigate the phosphoproteome in prostate cancer. J. Vis. Exp. 2018, 138, e57996. [CrossRef] [PubMed]

116. Kataya, A.R.A.; Muenchen, D.G.; Moorhead, G.B. A framework to investigate peroxisomal protein phosphorylation in Arabidopsis. Trends Plant Sci. 2019, 24, 366-381. [CrossRef] [PubMed]

117. Ma, C.; Reumann, S. Improved prediction of peroxisomal PTS1 proteins from genome sequences based on experimental subcellular targeting analyses as exemplified for protein kinases from Arabidopsis. J. Exp. Bot. 2008, 59, 3767-3779. [CrossRef]

118. Fukao, Y.; Hayashi, M.; Hara-Nishimura, I.; Nishimura, M. Novel glyoxysomal protein kinase, GPK1, identified by proteomic analysis of glyoxysomes in etiolated cotyledons of Arabidopsis thaliana. Plant Cell Physiol. 2003, 44, 1002-1012. [CrossRef]

119. Dammann, C.; y Ichida, A.; Hong, B.; Romanowsky, S.M.; Hrabak, E.M.; Harmon, A.C.; Pickard, B.G.; Harper, J.H. Subcellular targeting of nine calcium dependent protein kinase isoforms from Arabidopsis. Plant Physiol. 2003, 132, 1840-1848. [CrossRef]

120. Lee, H.Y.; Yoon, G.M. Kinase assay for CONSTITUTIVE TRIPLE RESPONSE 1 (CTR1) in Arabidopsis thaliana. Meth. Mol. Biol. 2017, 1573, 133-140.

121. Hodges, M.; Jossier, M.; Boex-Fontvieille, E.; Tcherkez, G. Protein phosphorylation and photorespiration. Plant Biol. (Stuttg) 2013, 15, 694-706. [CrossRef] [PubMed]

122. Pazmiño, D.M. Contribución de las Especies de Oxígeno y Nitrógeno Reactivo, y de los Peroxisomas a la Toxicidad del 2,4-d en Plantas. Ph.D. Thesis, University of Granada, Granada, Spain, 2009.

123. Zou, J.J.; Li, X.D.; Ratnasekera, D.; Wang, C.; Liu, W.Y.; Song, L.F.; Zhang, W.Z.; Wu, W.H. Arabidopsis CALCIUM-DEPENDENT PROTEIN KINASE8 and CATALASE3 Function in Abscisic Acid-Mediated Signaling and $\mathrm{H}_{2} \mathrm{O}_{2}$ Homeostasis in Stomatal Guard Cells under Drought Stress. Plant Cell 2015, 27, 1445-1460. [CrossRef] [PubMed]

124. Verslues, P.E.; Batelli, G.; Grillo, S.; Agius, F.; Kim, Y.S.; Zhu, J.; Agarwal, M.; Katiyar-Agarwal, S.; Zhu, J.K. Interaction of SOS2 with Nucleoside Diphosphate Kinase 2 and Catalases Reveals a Point of Connection between Salt Stress and $\mathrm{H}_{2} \mathrm{O}_{2}$ Signaling in Arabidopsis thaliana. Mol. Cell Biol. 2007, 27, 7771-7780. [CrossRef] [PubMed]

125. Rhee, S.G.; Yang, K.S.; Kang, S.W.; Woo, H.A.; Chan, T.S. Controlled elimination of intracellular $\mathrm{H}_{2} \mathrm{O}_{2}$ : Regulation of peroxiredoxin, catalase, and glutathione peroxidase via post-translational modification. Antioxid. Redox Signal. 2013, 7, 619-626. [CrossRef] [PubMed]

126. Sharma, B.; Joshi, D.; Yadav, P.K.; Gupta, A.K.; Bhatt, T.K. Role of ubiquitin-mediated degradation system in plant biology. Front. Plant. Sci. 2016, 7, 806. [CrossRef]

127. Platta, H.W.; El Magraoui, F.; Bäumer, B.E.; Schlee, D.; Girzalsky, W.; Erdmann, R. Pex2 and pex12 function as protein-ubiquitin ligases in peroxisomal protein import. Mol. Cell Biol. 2009, 29, 5505-5516. [CrossRef] [PubMed]

128. Burkhart, S.E.; Kao, Y.T.; Bartel, B. Peroxisomal ubiquitin-protein ligases peroxin2 and peroxin10 have distinct but synergistic roles in matrix protein import and peroxin5 retrotranslocation in Arabidopsis. Plant Physiol. 2014, 166, 1329-1344. [CrossRef]

129. Kao, Y.T.; Fleming, W.A.; Ventura, M.J.; Bartel, B. Genetic interactions between peroxin12 and other peroxisome-associated ubiquitination components. Plant Physiol. 2016, 172, 1643-1656. [CrossRef]

130. Song, G.; Walley, J.W. Dynamic Protein Acetylation in Plant-Pathogen Interactions. Front. Plant Sci. 2016, 7, 421. [CrossRef]

131. Chen, H.; Li, S.; Li, L.; Wu, W.; Ke, X.; Zou, W.; Zhao, J. Na-Acetyltransferases 10 and 15 are required for the correct initiation of endosperm cellularization in Arabidopsis. Plant Cell Physiol. 2018, 59, 2113-2128. [CrossRef]

132. Drazic, A.; Myklebust, L.M.; Ree, R.; Arnesen, T. The world of protein acetylation. Biochim. Biophys. Acta 2016, 1864, 1372-1401. [CrossRef] [PubMed]

133. Strasser, R. Plant protein glycosylation. Glycobiology 2016, 26, 926-939. [CrossRef] [PubMed] 
134. Arent, S.; Rye, V.E.; Henriksen, A. Structure and function of plant acyl-CoA osidase. Plant Physiol. Biochem. 2008, 46, 292-301. [CrossRef] [PubMed]

135. Yuan, H.M.; Liu, W.C.; Lu, Y.T. CATALASE2 coordinates SA-mediated repression of both auxin accumulation and JA biosynthesis in plant defenses. Cell Host Microb. 2017, 21, 143-155. [CrossRef] [PubMed]

136. Zhang, Z.; Xu, Y.; Xie, Z.; Li, Y.; He, Z.H.; Peng, X.X. Association-dissociation of glycolate oxidase with catalase in rice: A potential switch to modulate intracellular $\mathrm{H}_{2} \mathrm{O}_{2}$ levels. Mol. Plant. 2016, 9, 737-748. [CrossRef] [PubMed]

137. Anand, P.; Hausladen, A.; Wang, Y.J.; Zhang, G.F.; Stomberski, C.; Brunengraber, H.; Hess, D.T.; Stamler, J.S. Identification of S-nitroso-CoA reductases that regulate protein S-nitrosylation. Proc. Natl. Acad. Sci. USA 2014, 111, 18572-18577. [CrossRef] [PubMed]

138. Dixon, D.P.; Skipsey, M.; Grundy, N.M.; Edwards, R. Stress-induced protein Sglutathionylation in Arabidopsis. Plant Physiol. 2005, 138, 2233-2244. [CrossRef] [PubMed]

139. Tanou, G.; Filippou, P.; Belghazi, M.; Job, D.; Diamantidis, G.; Fotopoulos, V.; Molassiotis, A. Oxidative and nitrosative-based signaling and associated post-translational modifications orchestrate the acclimation of citrus plants to salinity stress. Plant J. 2012, 72, 585-599. [CrossRef]

140. Molassiotis, A.; Job, D.; Ziogas, V.; Tanou, G. Citrus plants: A model system for unlocking the secrets of no and ros-inspired priming against salinity and drought. Front. Plant Sci. 2016, 7, 229. [CrossRef] [PubMed]

141. Baena, G.; Feria, A.B.; Echevarría, C.; Monreal, J.A.; García-Mauriño, S. Salinity promotes opposite patterns of carbonylation and nitrosylation of $\mathrm{C} 4$ phosphoenolpyruvate carboxylase in sorghum leaves. Planta 2017, 246, 1203-1214. [CrossRef]

142. Gangwar, A.; Paul, S.; Ahmad, Y.; Bhargava, K. Competing trends of ROS and RNS-mediated protein modifications during hypoxia as an alternate mechanism of NO benefits. Biochimie 2018, 148, 127-138. [CrossRef] [PubMed]

143. Monteiro, H.P. Signal transduction by protein tyrosine nitration: Competition or cooperation with tyrosine phosphorylation-dependent signaling events? Free Radic. Biol. Med. 2002, 33, 765-773. [CrossRef]

144. Zhou, H.L.; Stomberski, C.T.; Stamler, J.S. Cross talk between S-nitrosylation and phosphorylation involving kinases and nitrosylases. Circ. Res. 2018, 122, 1485-1487. [CrossRef] [PubMed]

145. Farré, J.C.; Mahalingam, S.S.; Proietto, M.; Subramani, S. Peroxisome biogenesis, membrane contact sites, and quality control. EMBO Rep. 2019, 20, e46864. [CrossRef] [PubMed]

146. Bánréti, Á.; Sass, M.S.; Graba, Y. The emerging role of acetylation in the regulation of autophagy. Autophagy 2013, 9, 819-829. [CrossRef]

147. Oeljeklaus, S.; Schummer, A.; Mastalski, T.; Platta, H.W.; Warscheid, B. Regulation of peroxisome dynamics by phosphorylation. Biochim. Biophis. Acta 2016, 1863, 1227-1237. 